\title{
Impact of nanosilver on various DNA lesions and HPRT gene mutations - effects of charge and surface coating
}

Anna Huk ${ }^{1,2}$, Emilia Izak-Nau ${ }^{2,3}$, Naouale el Yamani ${ }^{1}$, Hilde Uggerud ${ }^{4}$, Marit Vadset ${ }^{4}$, Beata Zasonska ${ }^{5}$, Albert Duschl ${ }^{2}$ and Maria Dusinska ${ }^{1 *}$

\begin{abstract}
Background: The main goal of this research was to study the interactions of a fully characterized set of silver nanomaterials (Ag ENMs) with cells in vitro, according to the standards of Good Laboratory Practices (GLP), to assure the quality of nanotoxicology research. We were interested in whether Ag ENMs synthesized by the same method, with the same size distribution, shape and specific surface area, but with different charges and surface compositions could give different biological responses.

Methods: A range of methods and toxicity endpoints were applied to study the impacts of interaction of the Ag ENMs with TK6 cells. As tests of viability, relative growth activity and trypan blue exclusion were applied.

Genotoxicity was evaluated by the alkaline comet assay for detection of strand breaks and oxidized purines. The mutagenic potential of Ag ENMs was investigated with the in vitro HPRT gene mutation test on V79-4 cells according to the OECD protocol. Ag ENM agglomeration, dissolution as well as uptake and distribution within the cells were investigated as crucial aspects of Ag ENM toxicity. Ag ENM stabilizers were included in addition to positive and negative controls.

Results: Different cytotoxic effects were observed including membrane damage, cell cycle arrest and cell death. Ag ENMs also induced various kinds of DNA damage including strand breaks and DNA oxidation, and caused gene mutation. We found that positive Ag ENMs had greater impact on cyto- and genotoxicity than did Ag ENMs with neutral or negative charge, assumed to be related to their greater uptake into cells and to their presence in the nucleus and mitochondria, implying that Ag ENMs might induce toxicity by both direct and indirect mechanisms.

Conclusion: We showed that Ag ENMs could be cytotoxic, genotoxic and mutagenic. Our experiments with the HPRT gene mutation assay demonstrated that surface chemical composition plays a significant role in Ag ENM toxicity.
\end{abstract}

Keywords: Silver nanomaterials, Surface charge, Surface coating, Uptake and localization, Cytotoxicity, DNA damage, Genotoxicity/mutagenicity

\section{Background}

Silver in nano-form, called also engineered silver nanomaterials (Ag ENMs) or simply nanosilver, is of size less than $100 \mathrm{~nm}$, mostly at oxidation stage $\mathrm{Ag}^{0}$ with presence of $\mathrm{Ag}$ ions [1, 2]. Due to high reactivity, high temperature stability and low volatility, low cost of production and antibacterial properties, Ag ENMs are one of the most often used ENMs, and are present in a wide

\footnotetext{
* Correspondence: mdu@nilu.no

'Health Effects Laboratory, MILK, NILU, Kjeller, Norway

Full list of author information is available at the end of the article
}

range of products [3, 4]. Ag ENMs have applications in water purification filters, textiles, catalysts, food packages and cosmetics [5-8]. Nevertheless, the most profitable application of Ag ENMs is in medical products such as drug delivery, diagnostic tools, bone cement, coatings for orthopedic stockings and implants, and pharmaceuticals for dermatitis, acne and ulcerative colitis treatment [9-12]. Increasing numbers of products based on Ag ENMs demand relevant in vitro toxicology research on those materials, with special attention given

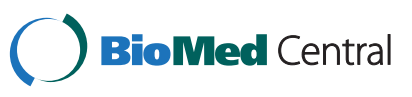

(c) 2015 Huk et al. This is an Open Access article distributed under the terms of the Creative Commons Attribution License (http://creativecommons.org/licenses/by/4.0), which permits unrestricted use, distribution, and reproduction in any medium, provided the original work is properly credited. The Creative Commons Public Domain Dedication waiver (http:// creativecommons.org/publicdomain/zero/1.0/) applies to the data made available in this article, unless otherwise stated. 
to correlate physical properties of Ag ENMs with harmful effects [13].

Intensive investigation of ENM toxicity in the last decade has brought many inconclusive and controversial results. A number of studies have reported cytotoxic effects of Ag ENMs, such as inhibition of cell proliferation, cell membrane damage, apoptosis and necrosis [14-19]. It was also found that Ag ENMs can interact with DNA, inducing different DNA lesions such as strand breaks, DNA oxidation and DNA adducts [15, 18-21]. In nanotoxicology research it is fundamentally important to understand the link between physico-chemical properties of ENMs and their toxicity, because even small changes in ENM structure can affect final biological responses [13, 22]. Ag ENMs are not uniform compounds but materials with different sizes, shapes, and with different surface charge, composition and functionalization. Previous toxicology evaluations of Ag ENMs were mostly focused on sizerelated toxicity [23-27] demonstrating significant impact of size on biological response. However, some studies suggest that not size but surface charge can play a crucial role in the mode of action of Ag ENMs [28, 29]. Suresch et al. [28] and el Badawy et al. [29] demonstrated that the cationic Ag ENMs are more toxic for both mammalian and bacterial cells. However, the correlation between surface charge and toxicity of Ag ENMs is not straightforward. Due to the fact that only one cationic Ag ENM has been tested in cited studies, it cannot be definitely proved that observed effects are only related to surface charge and not to surface chemical composition.

Therefore, to better understand the mechanism of $\mathrm{Ag}$ ENMs toxicity, in this study we focused most on effects of Ag ENM surface charge and surface composition on cell toxicity.

We tested six different Ag ENMs, two for each surface charge, from the same sources, synthesized by the same method and fully characterized by standard techniques. Two different stabilizers per charge were selected to distinguish between effects of surface charge and surface chemical composition. Trisodium citrate and sodium dodecyl sulphate (SDS) were selected to ensure a negative charge on Ag ENMs, BYK $9067^{\circ}$ and chitosan for a positive charge and Tween 80 and Disperbyk $192^{\circ}$ for a neutral charge. For the toxicity study, a range of different endpoints was addressed and standard methods have been applied.

In the present study we used the human Blymphoblastoid (TK6) cell line, and circulating blood cells. As a representative cell model for nanotoxicology studies, TK6 cells were validated in a previous study against human peripheral blood cells and they were found to be a relevant model for blood cells in nanotoxicology studies [30]. Additionally, to study mutations induced by ENMs, we used Chinese hamster lung fibroblast cells (V79-4) according to the test guideline OECD 476, as a continuation of our previous experiments on size-dependent mutagenicity of Ag ENMs [25].

\section{Materials and methods Ag nanomaterials}

Ag ENMs with the same size, shape and specific surface area but with different charges and surface compositions were synthesized by chemical reduction of silver nitrate $\left(\mathrm{AgNO}_{3}\right.$; Heraeus, Germany) using sodium borohydrate $\left(\mathrm{NaBH}_{4} ; \mathrm{ACROS}\right.$ Organics, Germany) (modified method of Creighton et al., [31]). A variety of coupling agents were used to stabilize ENMs from agglomeration: 3-sodium citrate $\left(\mathrm{Na}_{3} \mathrm{C}_{6} \mathrm{H}_{5} \mathrm{O}_{7}\right.$; Fisher Scientific, Germany) and sodium dodecyl sulfate (SDS; Sigma-Aldrich, Germany) negatively charged; chitosan (Sigma, Germany) and BYK- $9076^{\circ}$ (BYK-Chemie, Germany) - positively charged; Tween $80^{\circ}$ (Sigma-Aldrich, Germany) and Disperbyk-192 (BYK-Chemie, Germany) - neutral.

The investigated Ag ENMs were characterized by a combination of different techniques (Table 1). The average size/size distribution of primary Ag ENMs was determined by transmission electron microscopy (TEM; Phillips CM20, $200 \mathrm{keV}$ ) and dynamic light scattering (DLS; 90Plus, Brookhaven Instruments Corporation). TEM was additionally applied to define the Ag ENM shape. For TEM analysis, the stock dispersions were pipetted onto cobalt grids covered with polyvinyl formal/carbon (S162, Plano GmbH) and left to evaporate. A series of 10 images were selected to estimate the ENM size/size distribution using the analySiS pro software (Olympus). DLS measurements were performed in $10 \mathrm{~mm}$ polystyrene cuvettes at $25^{\circ} \mathrm{C}$ using a $\mathrm{He}-\mathrm{Ne}$ laser $(673 \mathrm{~nm})$. The ZetaPALS Particle Sizing Software ver. 4.10 was used to calculate the ENM size. The results are given as $\mathrm{Z}$-average values $( \pm \mathrm{SD})$ of the number, volume and intensity size distributions. The zeta potential was determined with the same equipment using phase analysis light scattering Zeta Potential Analyzer ver. 3.29. The DLS and zeta potential measurements were performed five times per batch of ENMs. The crystallite size and crystalline phase were evaluated by X-ray diffraction (XRD; PANalytical EMPYREAN PIXcel) at a voltage of $40 \mathrm{kV}$ and a current of $40 \mathrm{~mA}$ with $\mathrm{Cu} \mathrm{K \alpha}$ and $\mathrm{K} \beta$ radiation. The stock dispersions were dried onto a silicon surface. The chemical and elemental composition of the ENMs were examined by X-ray photoelectron spectroscopy (XPS; PHI VersaProbe 5000, MultiPack ver. 9.2 software) equipped with a monochromated $\mathrm{Al} \mathrm{K \alpha}$ X-ray beam scanned over an area of $600 \mu \mathrm{m} \times 400 \mu \mathrm{m}$ or $1400 \mu \mathrm{m} \times$ $100 \mu \mathrm{m}$ at a fixed take-off angle of $45^{\circ}$. The stock dispersions were dried onto an indium surface.

In addition, stability of Ag ENMs in cell culture medium (RPMI 1600, 10 \% FBS) was investigated with 
Table 1 Physical and chemical characterization of Ag ENMs

\begin{tabular}{|c|c|c|c|c|c|c|c|}
\hline \multirow[b]{2}{*}{ Name } & & \multicolumn{2}{|c|}{ Anionic Ag ENMs } & \multicolumn{2}{|l|}{ Neutral Ag ENMs } & \multicolumn{2}{|l|}{ Cationic Ag ENMs } \\
\hline & & Ag_Citrate & Ag_SDS & Ag_Disperbyk & Ag_Tween & Ag_Byk & Ag_Chitosan \\
\hline Stabilizer & & $\begin{array}{l}\text { Sodium citrate } \\
0.025 \%\end{array}$ & SDS $0.05 \%$ & $\begin{array}{l}\text { Disperbyk } \\
192^{\oplus} 0.05 \%\end{array}$ & $\begin{array}{l}\text { Tween } 80^{\circledast} \\
0.1 \%\end{array}$ & $\begin{array}{l}\text { BYK } 9076^{\oplus} 0.025 \% \\
\text { in } 0.05 \% \text { acetic } \\
\text { acid }\end{array}$ & $\begin{array}{l}\text { Chitosan } 0.05 \% \\
\text { in } 0.1 \% \text { acetic } \\
\text { acid }\end{array}$ \\
\hline \multirow[t]{2}{*}{ Surface charge $[\mathrm{mV}]^{a}$} & In solvent & $-42.26 \pm 1.64$ & $-33.23 \pm 0.90$ & $-3.02 \pm 4.12$ & $-1.13 \pm 1.73$ & $+26.56 \pm 1.67$ & $+52.40 \pm 1.79$ \\
\hline & $\begin{array}{l}\text { In RPMI } 1600 \\
\text { Medium }\end{array}$ & $-8.43 \pm 0.84$ & $-9.8 \pm 1.56$ & $-3,38 \pm 1.27$ & $-1.2 \pm 1.36$ & $-9.8 \pm 0.89$ & $-4,83 \pm 0.3$ \\
\hline $\begin{array}{l}\text { Surface chemistry } \\
\text { [Atom \%] }\end{array}$ & & $\begin{array}{l}\text { C 44.6; O 41.6; } \\
\text { Na 9.2; N 3.0; } \\
\text { Ag 1.7 }\end{array}$ & $\begin{array}{l}\text { C 48.1; O 40.2; } \\
\text { Na 5.9; Ag 3.6; } \\
\text { N 2.0; S } 0.2\end{array}$ & $\begin{array}{l}\text { C 72.8; O 24.5; } \\
\text { Ag 1.6; N 1.0 }\end{array}$ & $\begin{array}{l}\text { C 71.5; O 25.7; } \\
\text { Na 2.6; Ag } 0.2\end{array}$ & $\begin{array}{l}\text { C 69.5; O 16.3; } \\
\text { N 9.4; Ag 4.7 }\end{array}$ & $\begin{array}{l}\text { C 46.3; O 41.3; } \\
\text { N 7.3; Na 3.4; } \\
\text { Ag 1.7 }\end{array}$ \\
\hline \multirow{6}{*}{$\begin{array}{l}\text { Size/size distribution } \\
\& \text { aggregation/ } \\
\text { agglomeration } \\
\text { state }[\mathrm{nm}]^{\mathrm{a}}\end{array}$} & \multirow[t]{3}{*}{ In solvent } & DLS: 5.4 & DLS: 5.0 & DLS: 9.1 & DLS: 8.0 & DLS: 9.2 & DLS: - \\
\hline & & TEM: $5.9 \pm 2.3$ & TEM: $6.2 \pm 2.9$ & TEM: $6.9 \pm 2.8$ & TEM: $6.1 \pm 2.1$ & TEM: $10.5 \pm 2.5$ & TEM: $9.8 \pm 2.1$ \\
\hline & & XRD: 6.3 & XRD: 6.8 & XRD: 5.9 & XRD: 6.3 & XRD: 6.8 & XRD: 7.1 \\
\hline & \multirow{3}{*}{$\begin{array}{l}\text { In RPMI } 1600 \\
\text { medium }\end{array}$} & DLS: & DLS: & DLS: & DLS: & DLS: & DLS: \\
\hline & & P1: $133 \pm 67.56$ & P1: $137.4 \pm 78.24$ & P1: $391.5 \pm 10.9$ & P1: $49.73 \pm 10.9$ & $\mathrm{P} 1: 34.83 \pm 2.54$ & P1: $763.7 \pm 379.4$ \\
\hline & & $P 2: 22.04 \pm 9.2$ & P2: $17.14 \pm 5.31$ & $P 2: 41.18 \pm 10.3$ & & & P2: $127.4 \pm 37.93$ \\
\hline \multicolumn{2}{|l|}{ Shape } & spherical & spherical & spherical & spherical & spherical & spherical \\
\hline \multicolumn{2}{|l|}{ Crystal structure } & cubic & Cubic & cubic & cubic & cubic & cubic \\
\hline \multicolumn{2}{|l|}{$\begin{array}{l}\text { Concentration } \\
{[\mu \mathrm{g} / \mathrm{ml}]}\end{array}$} & 100 & 100 & 100 & 100 & 100 & 100 \\
\hline
\end{tabular}

a expressed as mean \pm SD of 3 independent replicates

Zetasizer Nano-ZS Model ZEN3600 (Malvern Instruments; Malvern, UK). Ag ENM stability was measured in $1.5 \mathrm{ml}$ disposable cuvettes (Kartell, Italy) and $0.5 \mathrm{ml}$ disposable folded capillary cells (for zeta potential measurements, Malvern, UK) at a controlled temperature of $37^{\circ} \mathrm{C}$ after $24 \mathrm{~h}$ incubation in cell culture medium.

\section{Cultivation of cells}

TK6 cells were obtained from the European Collection of Cell Culture (ECACC, Cat. 95111735). Cells were cultivated in RPMI 1640 culture medium (Sigma) supplemented with $10 \%$ heat-inactivated fetal bovine serum (FBS, $20 \mathrm{~min}, 55^{\circ} \mathrm{C}$ ), $100 \mathrm{U} / \mathrm{ml}$ penicillin and $100 \mu \mathrm{g} / \mathrm{ml}$ streptomycin in a humidified atmosphere $\left(5 \% \mathrm{CO}_{2}\right.$ and $37^{\circ} \mathrm{C}$ ).

Chinese hamster lung fibroblasts (V79-4) obtained from the European Collection of Cell Culture (ECACC, Cat.93010723) were cultured in flasks in DMEM low glucose medium (Sigma), with activated $10 \%$ FBS, 100 $\mathrm{U} / \mathrm{ml}$ penicillin and $100 \mu \mathrm{g} / \mathrm{ml}$ streptomycin and $200 \mathrm{mM}$ L-glutamine in a humidified atmosphere (5\% $\mathrm{CO}_{2}$ and $37^{\circ} \mathrm{C}$ ). Both cell lines were tested for Mycoplasma with the MycoAlert ${ }^{\mathrm{T} M}$ PLUS Mycoplasma Detection Kit, before use. This kit detects the activity of mycoplasmal enzymes (detects all the main mycoplasma contaminants). Tests were performed after the first passage and no mycoplasma contamination was detected.

\section{Treatment of cells}

TK6 cells were seeded in 24-well plates to evaluate the relative growth activity RGA, for TBE assay and for morphology observation, as well as in 96-well plates for the CA. To prepare cells for TEM, the cells were seeded in $100 \mathrm{~mm}$ Petri dishes at the density required. Volumes of exposure solutions and numbers of cells were adjusted to give equal Ag ENM concentrations in all assays. Ag ENM concentrations were expressed in mass units per $\mathrm{ml}(\mu \mathrm{g} / \mathrm{ml})$, per exposure surface $\left(\mu \mathrm{g} / \mathrm{cm}^{2}\right)$, per cell $(\mu \mathrm{g} / \mathrm{cell})$; or in surface area of ENMs per ml (calculated on the basis of primary ENM sizes), per exposure surface, per cell $\left(\mathrm{cm}^{2} / \mathrm{ml}, \mathrm{cm}^{2} / \mathrm{cm}^{2}, \mathrm{~cm}^{2} /\right.$ cell $)$. The information is summarized in Table 2.A. ENM mass per cell units of concentration was calculated in the following approach: Units $[$ ENM mass/cell $]=($ Ag ENM concentration $[\mu \mathrm{g} / \mathrm{ml}] *$ volume $) /$ number of exposed cells. V79-4 cell number was counted immediately before the exposure from an additional plate which was seeded in the same manner and number as for the experiment. TK6 cells were counted (by Automatic cell counter) immediately before the experiment.

Additional TK6 cells were treated with only the Ag ENM stabilizer at a concentration equal to the stabilizer 
Table 2 Concentrations of Ag ENMs (A) and Ag ENM stabilizers (B) applied for different assay. Ag ENM concentrations are expressed in mass units [per volume/per exposure area/per cell] and in area of ENMs [per volume/per exposure area/per cell]. Stabilizer concentrations are expressed in \% w/v

\begin{tabular}{|c|c|c|c|c|c|c|}
\hline & \multicolumn{6}{|c|}{ A: Ag ENMs concentrations } \\
\hline & \multicolumn{3}{|c|}{ Mass units } & \multicolumn{3}{|c|}{ Surface area of ENMs } \\
\hline & {$[\mu \mathrm{g} / \mathrm{ml}]$} & {$\left[\mathrm{\mu g} / \mathrm{cm}^{2}\right]$} & [pg/cell] & {$\left[\mathrm{cm}^{2} / \mathrm{ml}\right]$} & {$\left[\mathrm{cm}^{2} / \mathrm{cm}^{2}\right]$} & {$\left[\mathrm{cm}^{2} /\right.$ cell $]$} \\
\hline \multirow[t]{5}{*}{ CA RGA TBE CM } & 1 & 0.31 & \% 6.67 & 0.72 & 0.22 & $\sim 4.79 \times 10^{-6}$ \\
\hline & 2 & 0.63 & $\sim 13.33$ & 1.44 & 0.45 & $\sim 9.59 \times 10^{-6}$ \\
\hline & 4 & 1.25 & $\sim 26.67$ & 2.88 & 0.9 & $\sim 1.92 \times 10^{-5}$ \\
\hline & 8 & 2.5 & $\sim 53.33$ & 5.75 & 1.8 & $\sim 3.87 \times 10^{-5}$ \\
\hline & 10 & 3.13 & $\sim 66.67$ & 7.19 & 2.25 & $\sim 4.84 \times 10^{-5}$ \\
\hline \multirow[t]{3}{*}{ GMA } & 2 & 0.63 & $\sim 19.73$ & 1.44 & 0.45 & $\sim 1.42 \times 10^{-5}$ \\
\hline & 4 & 1.25 & $\sim 39.47$ & 2.88 & 0.9 & $\sim 2.84 \times 10^{-5}$ \\
\hline & 8 & 2.5 & $\sim 78.93$ & 5.75 & 1.8 & $\sim 5.68 \times 10^{-5}$ \\
\hline \multicolumn{7}{|c|}{$\begin{array}{l}\text { B: Ag ENM stabilizers } \\
\text { concentrations }\end{array}$} \\
\hline & Citrate & SDS & Disperbyk & Tween & Byk & Chitosan \\
\hline TBE & 0.0025 & 0.005 & 0.005 & 0.01 & 0.0025 & 0.005 \\
\hline RGA & 0.0025 & 0.005 & 0.005 & 0.01 & 0.0025 & 0.005 \\
\hline CM & 0.002 & 0.005 & 0.005 & 0.01 & 0.0025 & 0.005 \\
\hline CA & 0.002 & 0.004 & 0.004 & 0.008 & 0.002 & 0.004 \\
\hline GMA & 0.002 & 0.004 & 0.004 & 0.008 & 0.001 & 0.002 \\
\hline
\end{tabular}

TBE Trypan Blue exclusion assay, RGA Relative Growth activity, CM cells morphology, CA Comet assay, GMA Gene mutation assay

concentration used in the highest tested Ag ENM samples. Data are summarized in Table 2.B.

\section{Uptake and cellular localization}

TK6 cells were exposed to Ag ENMs $\left(2.5 \mu \mathrm{g} / \mathrm{cm}^{2}\right.$ : Ag Citrate, Ag_SDS, Ag_Disperbyk and Ag_Tween and $1.5 \mu \mathrm{g} /$ $\mathrm{cm}^{2}$ : Ag_Chitosan and Ag_Byk) in $100 \mathrm{~mm}$ Petri dishes $\left(7.8 \times 10^{6}\right.$ cells/Petri dish). After $24 \mathrm{~h}$ cells were fixed in $2.5 \%$ glutaraldehyde in $0.1 \mathrm{M}$ Sorensen phosphate buffer (pH 7.3) and left overnight. Next day, cells were washed with $0.1 \mathrm{M}$ Sorensen phosphate buffer $(\mathrm{pH}$ 7.3) and post-fixed in $1 \%$ osmium tetroxide in deionized water. Samples were dehydrated in increasing concentrations of ethanol (from 10 to $100 \%, 10 \mathrm{~min}$ each step, centrifuged every time at $200 \mathrm{~g}$ for $5 \mathrm{~min})$, immersed in ethanol/Epon (1:1 v/v) mixture and embedded in pure Epon $\left(2 \mathrm{~h}\right.$ at $37^{\circ} \mathrm{C}$ and polymerised for $24 \mathrm{~h}$ at $\left.60{ }^{\circ} \mathrm{C}\right)$. Sections $(\sim 80 \mathrm{~nm})$ were cut using a diamond knife on an ultra-microtome (Leica EM UC6) and mounted on copper grids. From each sample of exposed cells 5 grids with cell sections (approximate 20-40 cells per section) were prepared. Before image acquisition, sections were stained using uranyl acetate and lead citrate. All images were acquired on an FEI TECNAI 120 TEM (120 kV). Under investigation only the cells without damaged membrane (not in necrosis or advanced apoptosis) were taken. For each Ag ENM we tried to access minimum 20 images of individual ENMs. Experiments were run in triplicate.

\section{Trypan blue exclusion assay (TBE)}

To test for cell membrane integrity (assumed to be a measure of cell viability), TK6 cells $\left(4.4 \times 10^{5}\right.$ cells/well $)$ were exposed to Ag ENMs for 2 and $24 \mathrm{~h}$ at a range of concentrations $\left(0.31,0.63,1.25,2.5,3.13 \mu \mathrm{g} / \mathrm{cm}^{2}\right)$ in $6-$ well plates. After exposure, TK6 cells were disaggregated in the medium. About $10 \mathrm{ml}$ of cell suspension was mixed with $10 \mathrm{ml}$ trypan blue (0.4\%, Invitrogen) and viability (percentage of trypan blue positive cells) was measured using a Countess Automated Cell Counter (Invitrogen). Cell viability was determined according to the formula:

$$
T B E(\%)=\left(1-\frac{\text { number of steined cells }}{\text { number of total cells }}\right) \times 100 \%
$$

Six stabilizers were used as controls according to Table 2.B. Interference of Ag ENMs with Countess ${ }^{\mathrm{TM}} \mathrm{Au}-$ tomated Cell counter was studied in a cell-free system.

\section{Relative growth activity (RGA)}

To assess cell proliferation as well as cell death, TK6 cells $\left(4.4 \times 10^{5}\right.$ cells/well) were exposed to Ag ENMs for $24 \mathrm{~h}$ at a range of concentrations $(0.31,0.63,1.25,2.5$, $\left.3.13 \mu \mathrm{g} / \mathrm{cm}^{2}\right)$ in 6 -well plates. After $24 \mathrm{~h}$ exposure cells were disaggregated and counted using a Countess ${ }^{\mathrm{Tm}} \mathrm{Au}-$ tomated Cell Counter (Invitrogen). RGA was calculated according to the formula: 


$$
R G A(\%)=\frac{(\text { number of cells at day } 2 / \text { number of seeded cells at day } 0) \text { in exposed cultures }}{(\text { number of cells at day } 2 / \text { number of seeded cells at day } 0) \text { in unexposed cultures }} \times 100 \%
$$

Six stabilizers were used as controls according to Table 2.B.

\section{Cell morphology}

To observe changes in cell morphology, TK6 cells $\left(4.4 \times 10^{5}\right.$ cell/well $)$ were treated with Ag ENMs $\left(3.13 \mu \mathrm{g} / \mathrm{cm}^{2}\right)$ in 6-well plates for 2 and $24 \mathrm{~h}$ and observed under an optical microscope (Leica, model DM-IL). Images were captured under $100 \times$ magnification (Motic, model Motican 3 software Motic Images $2.0 \mathrm{ML}$ ). Cell morphology was analyzed visually by comparing about 300 images of untreated and treated cells. Six stabilizers were used as control according to Table 2.B.

\section{Comet assay (CA)}

Single-cell gel electrophoresis, the CA, is a sensitive and relatively simple method to study specific DNA lesions such as single and double strand breaks and DNA oxidation. Due to the high number of samples to be tested, we developed a very efficient semi-high-throughput method to analyze the genotoxic effect of Ag ENMs [32].

TK6 cells $\left(1.5 \times 10^{4}\right.$ cells /well $)$ were exposed in 96-well plates for 2 or $24 \mathrm{~h}$ at a range of concentrations $(0.31,0.63$, $1.25,2.5 \mu \mathrm{g} / \mathrm{cm}^{2}$ ). After exposure, $15-40 \mu \mathrm{l}$ of cell suspension were transferred to a 96 well U-bottom plate, and mixed with $200 \mu \mathrm{l}$ of LMP agarose (0.8\% in PBS). $10 \mu \mathrm{l}$ of this mixture was dropped on glass slides (pre-coated with $0.5 \%$ standard agarose) - 2 drops per concentration, 12 drops per slide. Slides were placed in cold lysis solution (2.5 M NaCl, 0.1 M EDTA, 10 mM Tris, 10 \% Triton X-100, $\mathrm{pH}$ 10). After overnight lysis, slides were submerged in alkaline solution (0.3 M NaOH, $1 \mathrm{mM}$ EDTA) for DNA unwinding for $20 \mathrm{~min}$, followed by electrophoresis at $1.25 \mathrm{~V} /$ $\mathrm{cm}$ for $20 \mathrm{~min}$ in a standard CA electrophoresis tank. Slides were then washed in PBS followed by cold water and allowed to dry overnight. Slides were stained with SybrGold $\left(0.1 \mathrm{l} / \mathrm{ml}\right.$ in TE buffer - $10 \mathrm{mM}$ TrisHCl, $1 \mathrm{mM} \mathrm{Na} \mathrm{EDTA}_{2}$, pH 7.5-8, Invitrogen), covered with a cover slip and examined with a fluorescence microscope (Leica DMI 6000 B). Images of comets were scored using image analysis Comet Assay IV software (Perceptive Instruments), calculating mean \% DNA in tail from 50 comets per gel.

For detection of DNA base oxidation we used the modified CA with the bacterial repair enzyme formamidopyrimidine DNA glycosylase (FPG, provided by Professor Andrew
Collins, University of Oslo, Norway) [33]. Just after lysis, slides were washed with FPG buffer (no enzyme) (40 mM HEPES, $0.1 \mathrm{M} \mathrm{KCl}, 0.5 \mathrm{mM}$ EDTA, $0.2 \mathrm{mg} / \mathrm{ml}$ bovine serum albumin, $\mathrm{pH}$ 8.0), placed in a special plate for enzyme incubation (Huk, NILU) and $30 \mu \mathrm{l}$ of FPG in this buffer was added to each gel. Slides were covered with polypropylene foil and incubated for $30 \mathrm{~min}$ at $37{ }^{\circ} \mathrm{C}$. Further steps were according to the standard $\mathrm{CA}$ protocol described above. Net FPG-sensitive sides (Net FPG) were calculated as the difference in \% DNA in tail between samples with FPG incubation and samples with buffer incubation. As positive control for strand breaks (SBs), cells were treated with hydrogen peroxide (Sigma, $50 \mu \mathrm{M}, 5 \mathrm{~min}$ on ice). As positive control for FPG-sensitive sites, cells were treated with the photosensitiser Ro19-8022 (Hoffman La Roche) plus visible light ( $1 \mu \mathrm{M}$ in PBS, $5 \mathrm{~min}$, on ice). Six stabilizers were used as controls according to Table 2.B.

\section{Mammalian in vitro HPRT gene mutation test, OECD 476} V-79-4 cells were plated on 6 -well plates $\left(1 \times 10^{5}\right.$ cells per well) and incubated at $37^{\circ} \mathrm{C}$. After $24 \mathrm{~h}$, the cells were exposed to Ag ENMs for $24 \mathrm{~h}$ at a range of concentrations $\left(0.63,1.25,2.5 \mu \mathrm{g} / \mathrm{cm}^{2}\right)$. After exposure, medium was removed; cells were washed with PBS, trypsinized and resuspended in $2 \mathrm{ml}$ medium. $10^{6}$ cells were seeded in $100 \mathrm{~mm}$ Petri dishes $\left(3.5 \times 10^{5}\right.$ cells/Petri dish, 3 dishes per sample to achieve $10^{6}$ cells per sample), grown in culture medium for 8 days, and split at days 3 and 5. Cells were harvested for mutant analysis at day 6 and 8 after treatment: cells were inoculated in $100 \mathrm{~mm}$ Petri dishes $\left(2 \times 10^{5}\right.$ cells/Petri dish, 5 dishes per sample to achieve $10^{6}$ cells per sample). Cells were grown in selective medium containing 6-thioguanine (final concentration $5 \mu \mathrm{g} / \mathrm{ml}$ ) for 10 days to form colonies. Mutant (6-thioguanine-resistant) colonies were stained with $1 \%$ methylene blue and counted manually. Only colonies comprising at least 50 cells were counted.

For measurement of cell survival (plating efficiency,

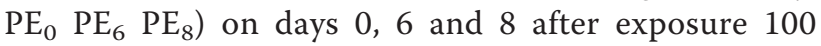
cells were plated into 6-well plates (100 cells per well, 1 plate for each sample) and incubated for 7 days. Cells were then stained with $1 \%$ methylene blue and counted manually. Thus survival was determined at the time of each mutation harvest and calculated on 
the basis of the number of colonies versus the number of inoculated cells.

Mutant frequency was calculated according to the following formula:

$$
\text { Mutant frequency }\left(x 10^{6}\right)=\frac{\text { number of mutant colonies }}{\text { number of surviving inoculated cells }} \times 100
$$

PE was calculated according to the following formula:

$$
P E(\%)=\frac{\text { number of colonies in exposed cultures }}{\text { number of colonies in unexposed cultures }} \times 100 \%
$$

Cells treated with methyl methanesulfonate (MMS; $0.03 \mathrm{mM} ; 30 \mathrm{~min}$, Sigma) were used as positive control. Six stabilizers were used as controls according to Table 2.B.

Release of $\mathrm{Ag}$ ions from Ag ENMs in a biological medium Concentrations of $\mathrm{Ag}$ ions in Ag ENM samples were evaluated by inductively coupled plasma mass spectrometry (ICP-MS) and expressed as \% of total Ag in Ag ENMs stocks. Ag ions were isolated from Ag ENMs by (a) extraction (Izak-Nau E, Huk A, Reidy B, Uggerud H, Vadset M, Eiden S, Voetz M, Duschl A, Dušinska $M$, Lynch I: Impact of Storage Conditions and Storage Time on Silver Nanoparticle Physicochemical Properties and Implications for Biological Effects. Manuscript in preparation) and (b) by ultracentrifugation $[\mathrm{s}=200000 \mathrm{~g}, \mathrm{t}=1 \mathrm{~h}]$.

In addition, ICP-MS was applied to quantify release of $\mathrm{Ag}$ ions after incubation of Ag ENMs in RPMI culture medium for $24 \mathrm{~h}$ in a $\mathrm{CO}_{2}$ incubator at $37{ }^{\circ} \mathrm{C}$. Samples were then ultracentrifuged (200 $000 \mathrm{~g})$ for $1 \mathrm{~h}$. Supernatants were collected, mineralized with concentrated nitric acid (nitric acid ultrapure, Sigma) and analyzed by ICP-MS (Agilent Technologies 7700x Series).

\section{Statistical analysis}

Data are expressed as mean \pm SD of 3 independent experiments. The differences between the untreated controls and the treatment groups were calculated by one-way analysis of variance (ANOVA) and posttests were analyzed using Tukey's test, to evaluate significant levels. Graph Pad Prism software, Microsoft ${ }^{\bullet}$ Excel and Daniels XL toolbox were used.

\section{Results}

\section{Characterization of Ag ENMs}

The Ag ENM characteristics are summarized in Table 1. DLS, TEM and XRD data indicated the ENM size to be in the region of $5-10 \mathrm{~nm}$. In the case of DLS, the size analysis of Ag ENMs stabilized by chitosan was not possible to perform in solvent (the size exceeds $1 \mu \mathrm{m})$. Since the size of those Ag ENMs was confirmed by TEM and XRD (TEM: $9.8 \pm$ $2.1 \mathrm{~nm}$, XRD: $7.1 \mathrm{~nm}$ ), it can be concluded that the big molecules of chitosan (which are normally not detected by TEM and XRD) disturbed the DLS analysis. TEM images also showed a quasi-spherical shape and monodispersal of the ENMs (Fig. 1). The characterization of Ag ENMs in cell culture medium (RPMI 1600; $10 \%$ heat activated serum) showed the agglomeration state of the ENMs and changes in surface charges of cationic and anionic Ag ENMs.

\section{Uptake and subcellular localization of Ag ENMs of different charge and surface compositions}

The uptake and subcellular localization of the Ag ENMs were confirmed using TEM. First, the images confirmed that all tested Ag ENMs were taken up by TK6 cells after exposure duration of $24 \mathrm{~h}$ (Fig. 2). Positively charged ENMs, Ag_Byk and Ag_Chitosan were the only Ag ENMs found in nuclei (Fig. 2b, g). Ag_Chitosan was detected in nuclei, vacuoles and mitochondria, and was present mostly as large Ag ENM agglomerates (Fig. 2f, g, h). Ag_Byk was present in nuclei and cytoplasm, as small Ag ENM clusters or single ENMs (Fig. 2a, b). Additionally we detected single, non-agglomerated Ag ENMs in organelles with membranes, probably deformed vacuoles (picture not shown). Ag ENMs, with negative and neutral charge were not observed to interact directly with mitochondria or nuclei in any of the images assessed. Agglomerates of Ag_SDS, Ag_Tween and Ag_Citrate were detected in cytoplasm (Fig. 2c, d, e, k). Ag_Disperbyk was located in vesicles, very close to the cell surface or in cytoplasm (Fig. 2j). The extent of Ag ENM intracellular localization could not be fully evaluated, due to their high toxicity. In tested concentrations many cells in stages of necrosis and apoptosis were observed. Due to cytoplasm condensation, detection of Ag ENMs was difficult. It is possible that small (not agglomerated) ENMs bypassed detection.

\section{Impact of Ag ENM charge and surface composition on cell proliferation and cell membrane damage}

The effect of Ag ENMs with different charge (negative: Ag_Citrate and Ag_SDS; neutral: Ag_Disperbyk and Ag_Tween; positive: Ag_Chitosan and Ag_Byk) on membrane damage and proliferation of TK6 cells was examined after 2 and $24 \mathrm{~h}$ exposure using TBE and RGA. Ag ENM stabilizers were used as controls and the concentration of stabilizer corresponds to the concentration of stabilizer in the highest concentration of Ag ENMs. Data are presented relative to the control cells that had no Ag ENM treatment 

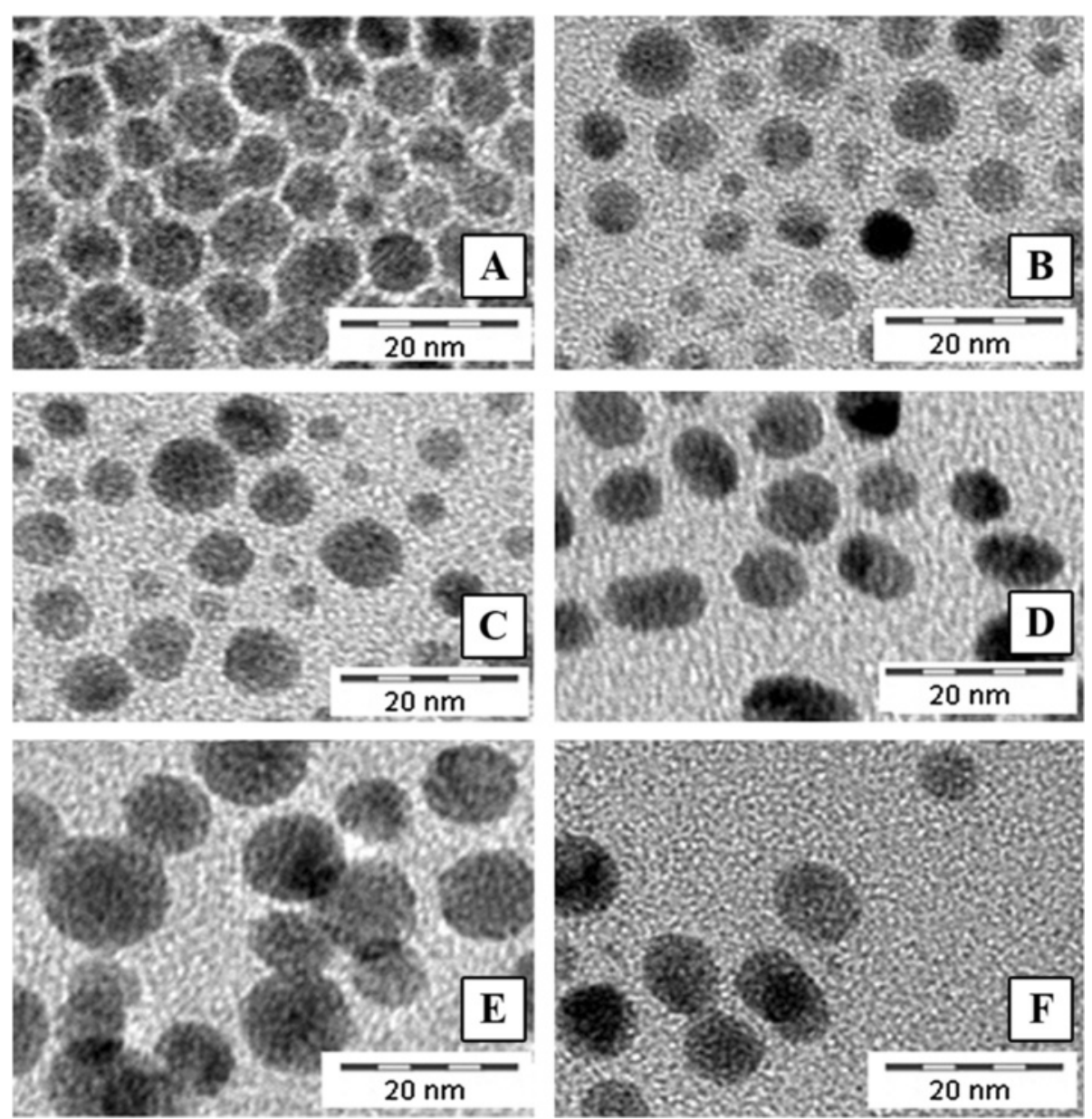

Fig. 1 TEM characterization of pristine Ag ENMs: (a) Ag_Citrate, (b) Ag_SDS, (c) Ag_Disperbyk, (d) Ag_Tween, (e) Ag_Chitosan, (f) Ag_Byk

(negative control). A clear concentration response in RGA was observed for almost all tested ENMs (except Ag_Disperbyk). Positively charged Ag ENMs, Ag_Chitosan and Ag_Byk were considered the most cytostatic of all tested materials (Figs. 3 and 4). Also only positively charged Ag ENMs caused cell membrane damage, already evident during the $2 \mathrm{~h}$ exposure. Of the tested Ag ENM stabilizers, none had toxic effects at tested concentration (data not shown).

\section{Impact of Ag ENM charge and surface composition on cell morphology}

Morphological changes of TK6 cells exposed to Ag ENMs with different charge and surface coating were observed using an optical microscope (Fig. 5). After $2 \mathrm{~h}$ exposure, changes of cellular morphology were observed in cells treated with Ag Byk ENMs compared to untreated cells. After short exposure cells were shrunken and irregular in shape. In samples with Ag Chitosan, clumps of cells were observed. However, the same changes were seen in cells treated with chitosan without Ag ENMs. After $24 \mathrm{~h}$ exposure, changes in cell morphology, such as shrunken cells with irregular shape, were observed in all samples. After $24 \mathrm{~h}$, fewer or no colonies were observed, which strongly suggests that Ag ENMs had an impact on cell proliferation. No morphology changes were observed in stabilizer controls except for cells treated with chitosan, where characteristic "protein structures" were observed. This could be explained by precipitation of chitosan in biological media at $\mathrm{pH} \sim 7$ or by interaction of chitosan with protein.

\section{Impact of Ag ENM charge and surface composition on level of DNA strand breaks}

The standard alkaline CA was employed for detection of single- and double-strand breaks in TK6 cells exposed to Ag ENMs with 3 different charges 


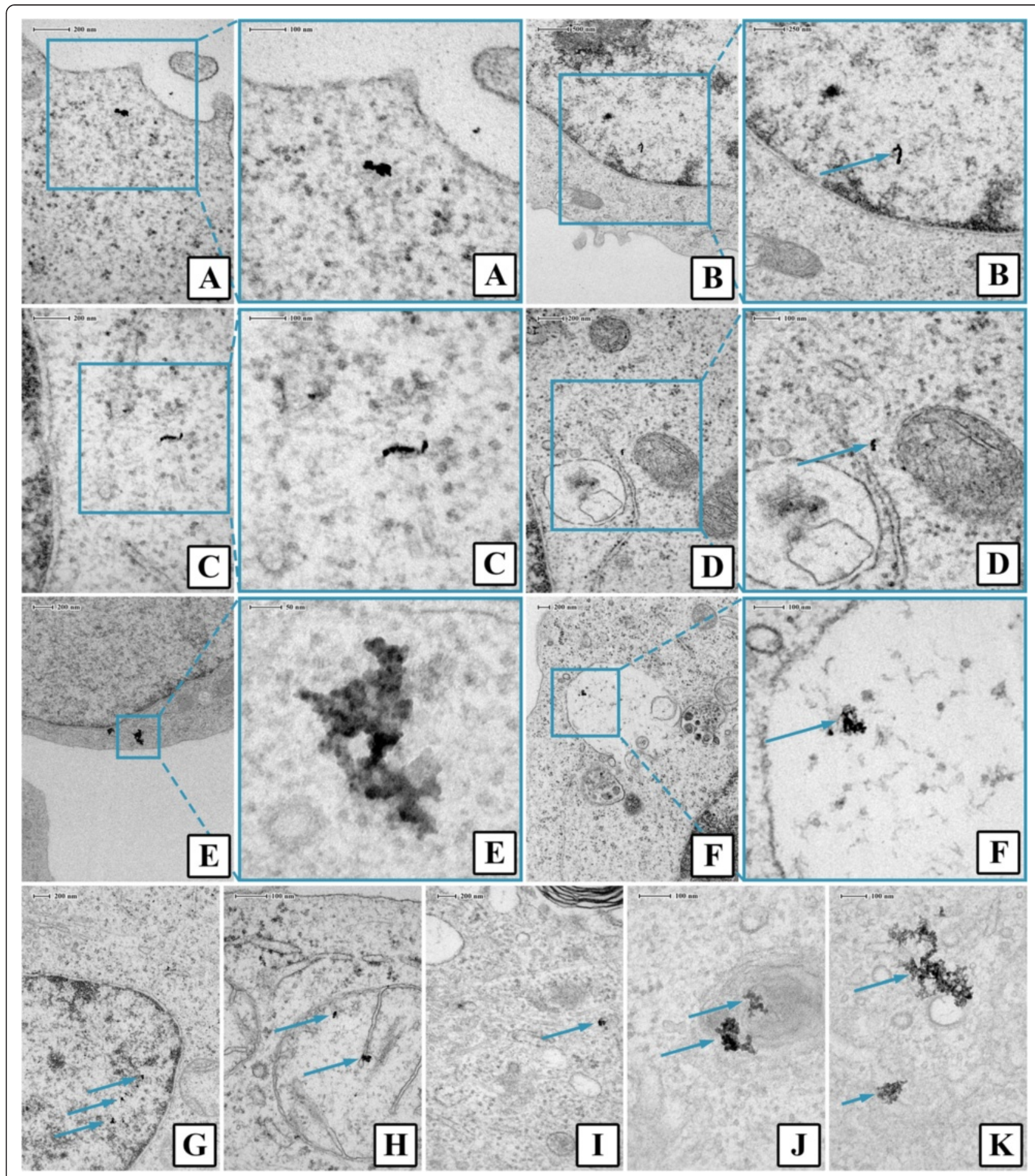

Fig. 2 Cellular localisation of different Ag ENMs in TK6 cells after 24 h exposure. a Ag_Byk in cytoplasm; (b) Ag_Byk in nucleus; (c) Ag_Citrate in cytoplasm; (d) Ag_Citrate in cytoplasm; (e) Ag_SDS in cytoplasm; (f) Ag_Chitosan in vacuoles; (g) Ag_Chitosan in nucleus; (h) Ag_Chitosan in mitochondrion; (i) Ag_Disperbyk in cytoplasm; (j) Ag_Disperbyk in membrane structure; (k) Ag_Tween in cytoplasm

(negative: Ag_Citrate and Ag_SDS; neutral: Ag_Disperbyk and Ag_Tween; positive: Ag_Chitosan and Ag_Byk) (Figs. 6 and 7). Two different time points were investigated; 2 and $24 \mathrm{~h}$. Ag ENM stabilizers were used as controls. The strongest effects were observed for positively charged Ag ENMs, already after 


\section{$2 \mathrm{~h}$ exposure}
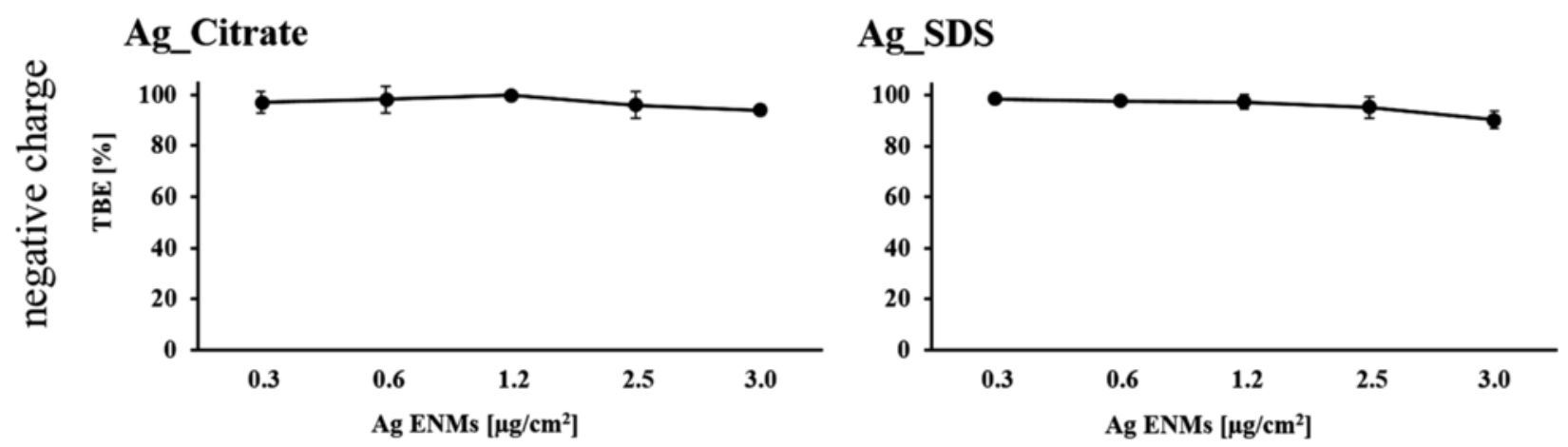

Ag_Disperbyk

Ag_Tween
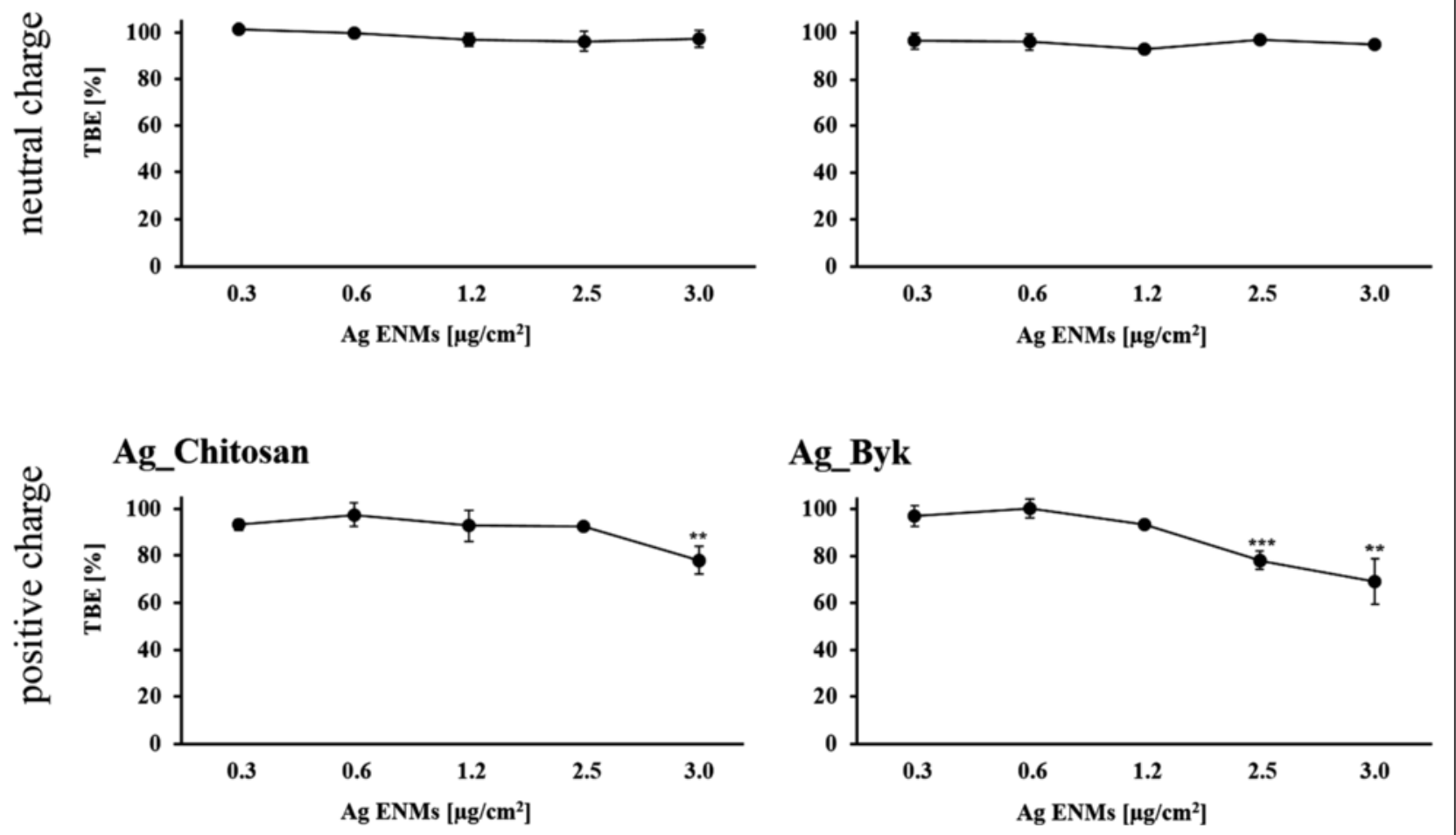

Fig. 3 Cytotoxic and cytostatic effects of Ag ENMs with different charge (negative: Ag_Citrate and Ag_SDS; neutral: Ag_Disperbyk and Ag_Tween; positive: Ag_Chitosan and Ag_Byk) on TK6 cells measured as trypan blue exclusion (TBE) Cells were treated with 5 concentrations $\left(\mu \mathrm{g} / \mathrm{cm}^{2}\right)$ of Ag ENMs for $2 \mathrm{~h}$ and cell number was counted immediately after the exposure. Graphs represent cytotoxicity relative to $100 \%$ of control. The data are expressed as mean \pm SD of three independent experiments. $P$ values indicate statistically significant results; ${ }^{*} p<0.05$; ${ }^{* *} p<0.01 ;{ }^{* * *} p<0.001$

$2 \mathrm{~h}$ exposure. High levels of strand breaks were also present at the highest tested concentration $\left(2.5 \mu \mathrm{g} / \mathrm{cm}^{2}\right)$ but could not be evaluated due to software limitation (DNA damage: $>70 \%$ tail intensity). However, Ag_Chitosan and Ag_Byk were also found to induce toxic effects (RGA 60-80 \%) (Fig. 7). Slight but significant increases in DNA breaks were found also in cells exposed to Ag_Citrate. Neutral charge Ag ENMs, and also Ag ENMs coated with SDS, did not cause DNA damage after short exposure. We found that after long-term exposure all tested Ag ENMs induce DNA damage. However the level of DNA damage could not be fully evaluated for cationic ENMs as comets/cells were not detected under the 


\section{$24 \mathrm{~h}$ exposure}

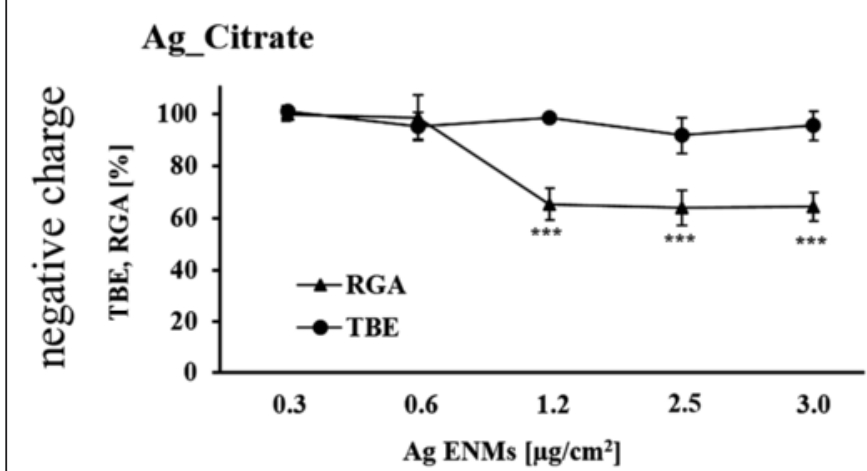

Ag_Disperbyk

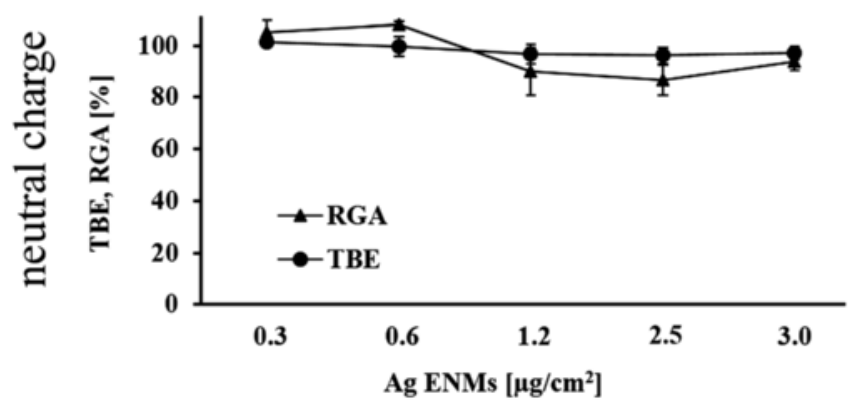

Ag_Chitosan

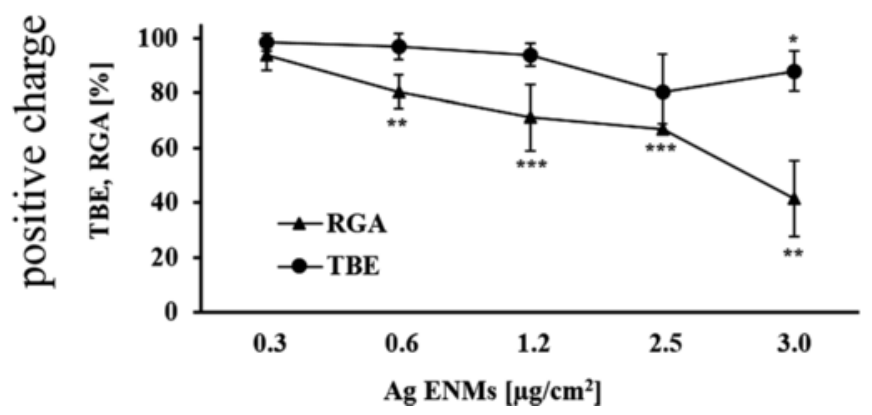

Ag_SDS

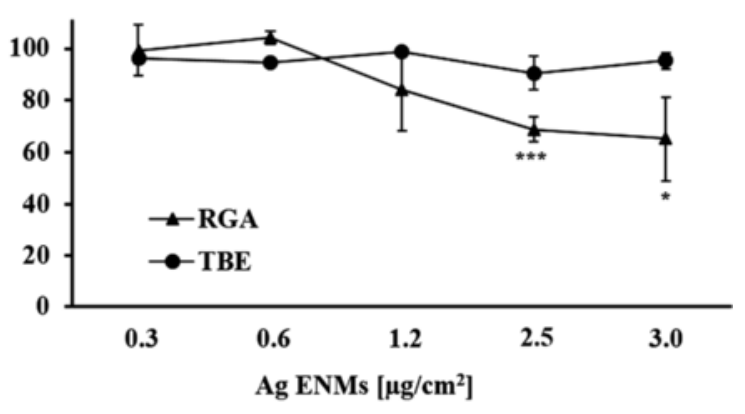

Ag_Tween

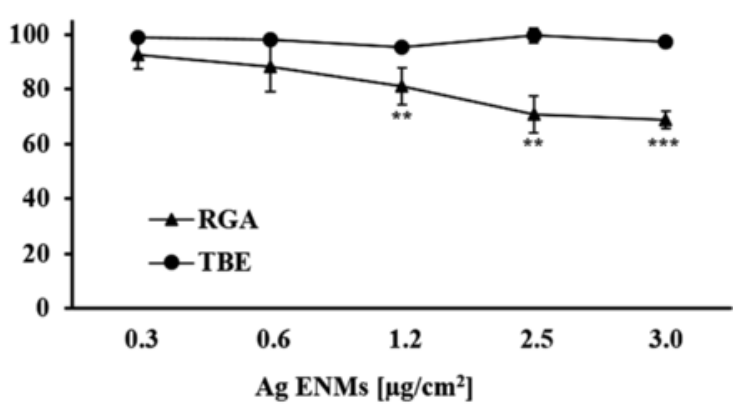

Ag_Byk

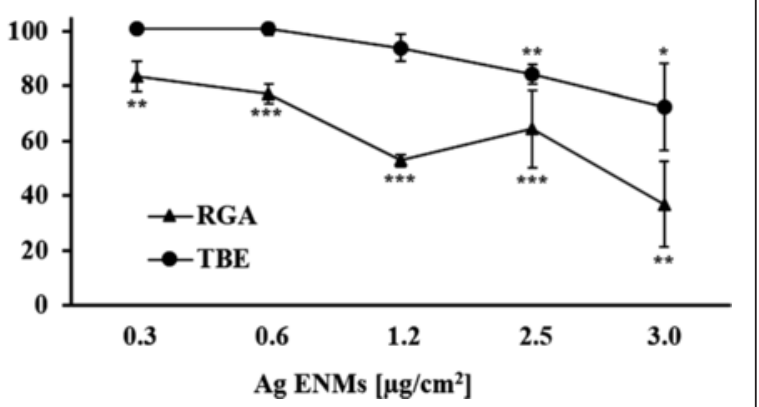

Fig. 4 Cytotoxic and cytostatic effects of Ag ENMs with different charge (negative: Ag_Citrate and Ag_SDS; neutral: Ag_Disperbyk and Ag_Tween; positive: Ag_Chitosan and Ag_Byk) on TK6 cells measured as trypan blue exclusion (TBE) and Relative growth activity (RGA). Cells were treated with 5 concentrations $\left(\mu \mathrm{g} / \mathrm{cm}^{2}\right)$ of Ag ENMs for $24 \mathrm{~h}$ and cell number was counted immediately after the exposure. Graphs represent cytotoxicity relative to $100 \%$ of control. The data are expressed as mean \pm SD of three independent experiments. $P$ values indicate statistically significant results; ${ }^{*} p<0.05 ;{ }^{* *} p<0.01$; ${ }^{* *} p<0.001$

microscope. Ag_Citrate and Ag_Disperbyk increased DNA damage at a concentration of $1.2 \mu \mathrm{g} / \mathrm{cm}^{2}$ but statistically significant differences were not found. No increases in DNA damage were seen for any of the tested Ag ENM stabilizers at either time point. Summing up, we conclude that the impact of Ag ENMs on the level of strand breaks is both chargeand surface coating-dependent.
Impact of Ag ENM charge and surface composition on level of DNA oxidation

The modified CA was employed for detection of DNA oxidation in TK6 cells exposed to Ag ENMs with different charges following the same conditions as mentioned above (Figs. 6 and 7). Results indicated that almost all tested Ag ENMs induced DNA oxidation and the level of DNA oxidation was similar to the level of strand breaks. 


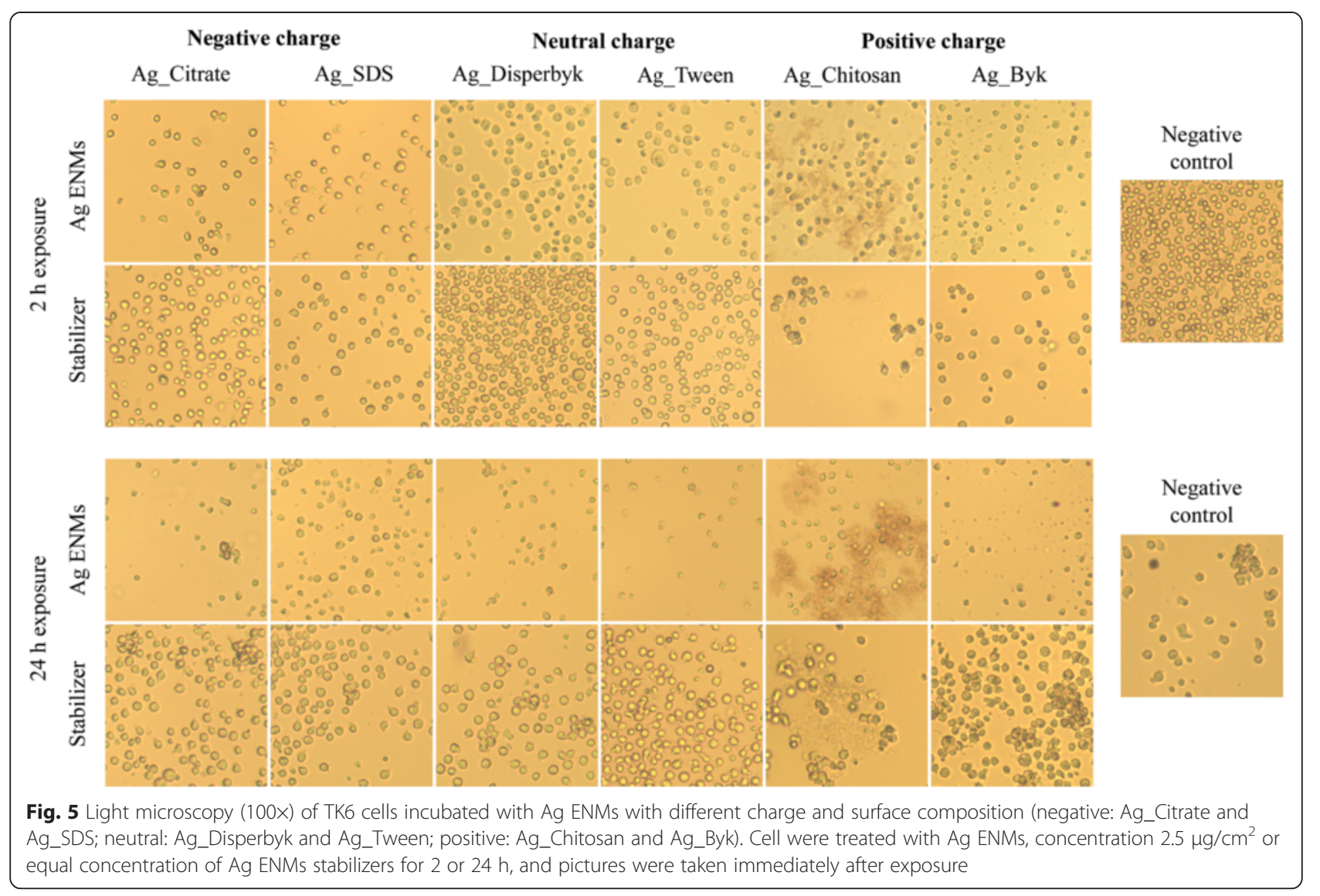

Among all the tested materials, Ag ENMs stabilized by SDS were found to be the least genotoxic; only a slight (in the range of background level), but statistically significant, increase in DNA oxidation was detected.

\section{Impact of Ag ENM charge and surface composition on gene mutation in V79-4 cells}

The mutagenic potential of Ag ENMs with different charges was examined by the HPRT gene mutation assay according to OECD guideline 476 (Fig. 8). Three independent experiments, each with two mutant harvests, were performed with V79-4 cells. Cytotoxic effects were investigated in parallel with the PE assay (Fig. 9). Ag ENM stabilizers were used as controls. All tested materials induced HPRT gene mutations in V79-4 cells; however, the mutagenic potential of Ag ENMs is not chargebut only surface coating-dependent. The highest level of mutants was found in cells exposed to Ag_Byk which also showed highest cytotoxicity (measured by PE). Of six tested Ag ENM stabilizers, sodium citrate and Tween have a strong impact on induction of gene mutants. The level of mutants in cells treated with Ag ENMs stabilized by citrate is equal to the level of mutants found in the stabilizer control. Sodium citrate and Tween showed no cytotoxicity (PE assay).
Release of $\mathrm{Ag}$ ions from $\mathrm{Ag}$ ENM in a biological medium Amounts of dissolved Ag ions after $24 \mathrm{~h}$ incubation in protein-supplemented cell culture medium were evaluated by ICP-MS (Table 3). We found that Ag ENM surface charge and chemical composition had no impact on Ag ENM dissolution rate. Relatively similar concentrations of released $\mathrm{Ag}$ ions were observed in all tested samples.

\section{Discussion}

Risk assessment strategies for ENM testing require relevant in vitro toxicology data, based on well-designed experiments. In vitro tests can be successfully applied in nanotoxicology studies. However, reference and quality standards should always be included: materials with well-defined physico-chemical properties, range of controls (including stabilizer controls) and representative cell models are crucially important. Also physical processes such as dissolution, aggregation and sedimentation should be taken into consideration to better understand the mechanism of ENM toxicity. The main reason for our study was to investigate the impact of surface charge and chemical composition of Ag ENMs on viability, genotoxicity and mutagenicity. As the most common cell model for genotoxicity and mutagenicity studies, V79-4 and TK6 cells 


\section{$2 \mathrm{~h}$ exposure}
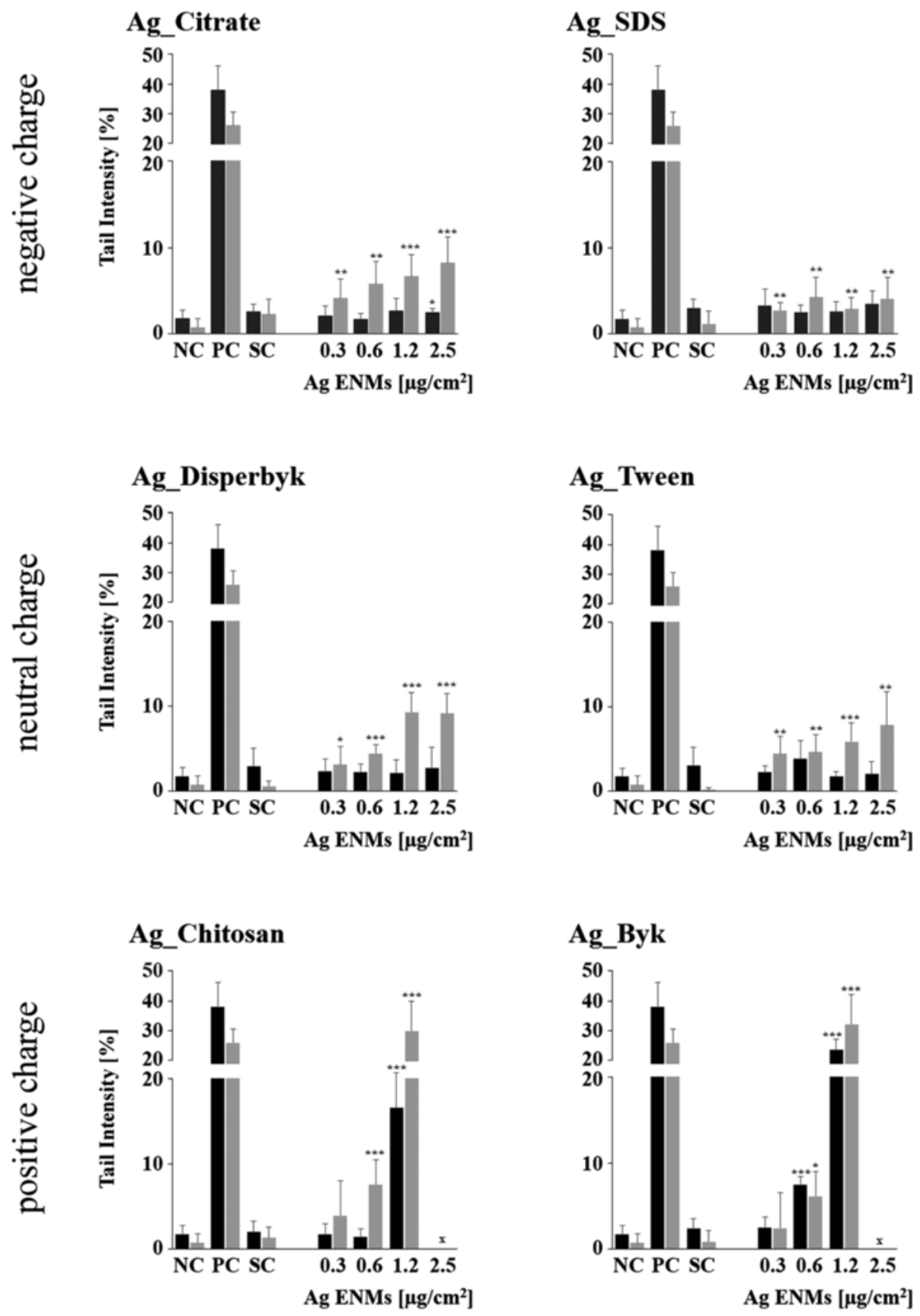

\section{SBs}

Net FPG

Fig. 6 Effects of surface charge and surface coating on Ag ENMs genotoxicity in TK6 cells. DNA damage (strand breaks and oxidised DNA lesions expressed as Net FPG) measured by the Comet assay in TK6 cells exposed to six different Ag ENMs for $2 \mathrm{~h}$ Data are presented as mean values \pm SD. $P$ values indicate statistically significant results; ${ }^{*} p<0.05 ;{ }^{* *} p<0.01$; ${ }^{* *} p<0.001$. NC - negative control; $\mathrm{PC}$ - positive control (strand breaks: $\mathrm{H}_{2} \mathrm{O}_{2}$ :

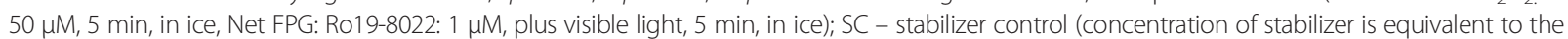
concentration of stabilizer in Ag ENMs $2.5 \mu \mathrm{g} / \mathrm{cm}^{2}$ ). x -level of DNA damage could not be fully evaluated, due to strong cytotoxicity 


\section{$24 \mathrm{~h}$ exposure}
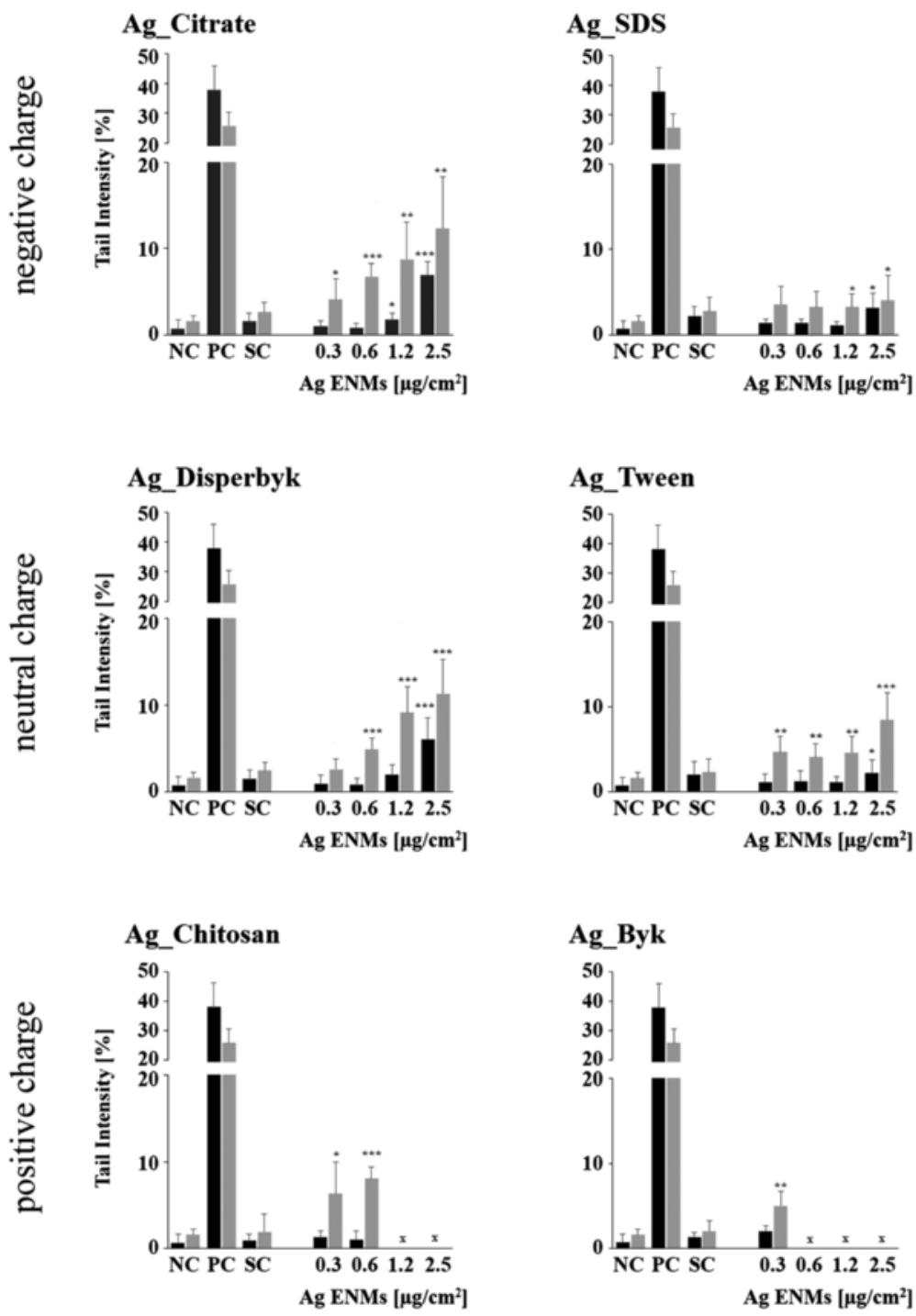

SBs

Net FPG

Fig. 7 Effects of surface charge and surface coating on Ag ENMs genotoxicity in TK6 cells. DNA damage (strand breaks and oxidised DNA lesions expressed as Net FPG) measured by the Comet assay in TK6 cells exposed to six different Ag ENMs for $24 \mathrm{~h}$. Data are presented as mean values \pm SD. $P$ values indicate statistically significant results; ${ }^{*} p<0.05 ;{ }^{* *} p<0.01 ;{ }^{* * *} p<0.001$. NC - negative control; $\mathrm{PC}$ - positive control (strand breaks: $\mathrm{H}_{2} \mathrm{O}_{2}$ : $50 \mu \mathrm{M}, 5 \mathrm{~min}$, in ice, Net FPG: Ro19-8022: $1 \mu \mathrm{M}$, plus visible light, $5 \mathrm{~min}$, in ice); SC - stabilizer control (concentration of stabilizer equivalent to concentration of stabilizer in Ag ENMs $2.5 \mu \mathrm{g} / \mathrm{cm}^{2}$ ). $\mathrm{x}$ - level of DNA damage could not be fully evaluated, due to strong cytotoxicity

were used. Additionally, ENM aggregation and dissolution in cell culture medium, as well as uptake and subcellular localization were investigated as crucial aspects of ENM toxicity. Data from all experiments are summarized in Table 4.

In the last decade, the toxicity of Ag ENMs has been widely investigated, using different model systems: stem cells or cell lines, bacteria, higher plants and fungi $[1,5,7,8,14-21,34]$. Comparison of nanotoxicology results between studies and research approaches is a challenge, mostly because of variance in tested materials and differences in conditions of experiments. Most researchers in nanotoxicology express ENM concentrations in mass units, usually $\mu \mathrm{g} / \mathrm{ml}$. From our previous work, we conclude that when comparing materials with different size and surface area, it is more useful and realistic to express concentrations as number of ENMs or as surface area of ENMs, than as mass units [25]. ENMs can change during exposure, mostly due to reactions with biomolecules present in 

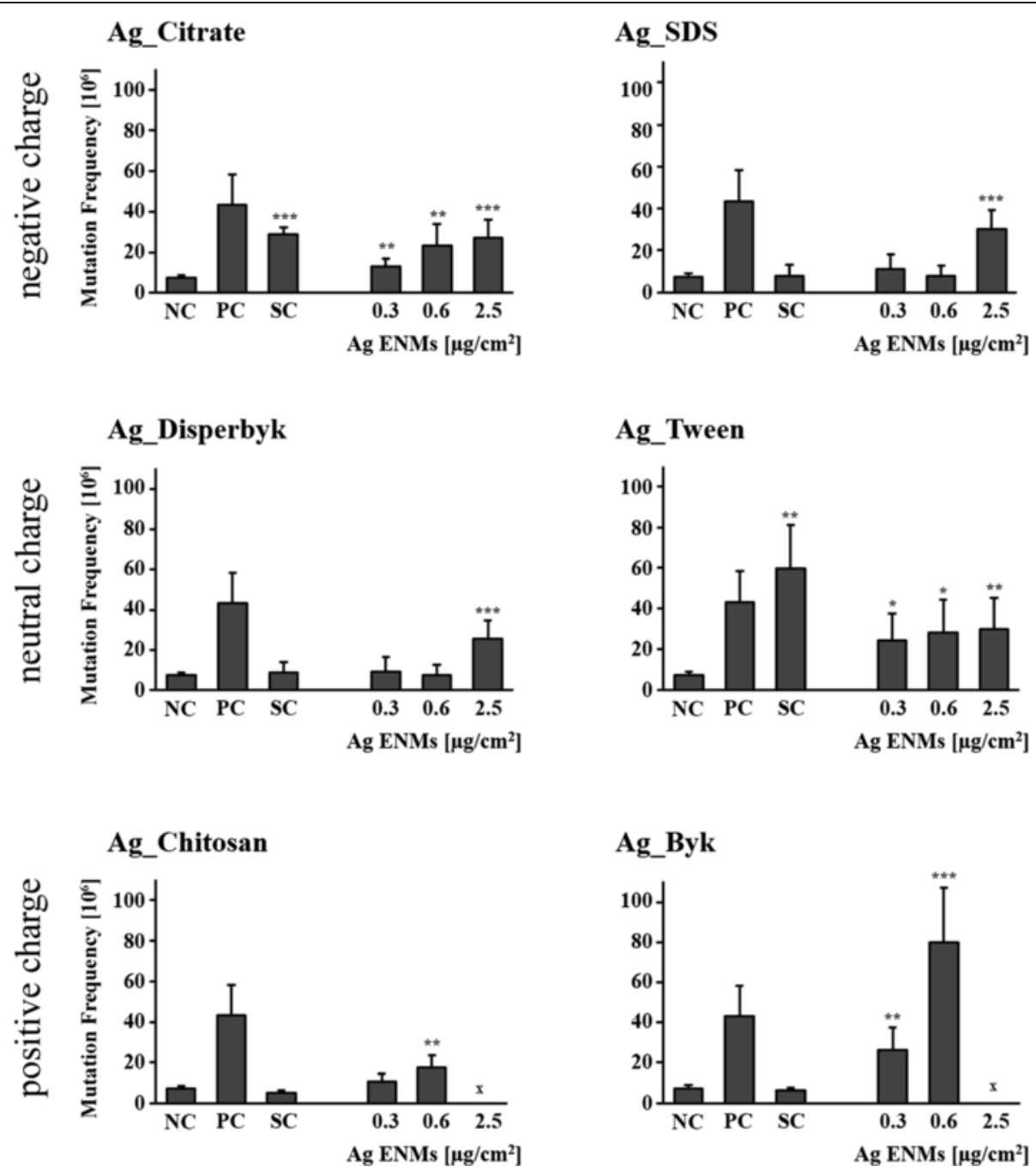

Fig. 8 Effects of surface charge and surface coating on Ag ENMs on induction of HPRT gene mutations in V79-4 cells. Cells were treated with 3 different concentrations of Ag ENMs and Ag ENM stabilizer equivalent to stabilizer concentrations in highest tested concentrations of Ag ENMs. The mutant frequencies $\left(\times 10^{6}\right)$ are expressed as mean \pm SD of three independent experiments, with two independent harvests per experiment. MMS (0.03 $\mu \mathrm{M}, 30 \mathrm{~min})$ was used as a positive control. NC - negative control; PC - positive control (MMS; $0.03 \mu \mathrm{M}, 30$ min), SC - stabilizer control . For Ag_Byk and Ag_Chitosan level of mutants could not be fully evaluated, due to strong cytotoxicity. Significant difference from unexposed control $\left({ }^{*} p<0.05,{ }^{* *} p<0.01,{ }^{* * *} p<0,001\right)$

the medium, for example proteins binding to the surface of ENMs, affecting their aggregation and sedimentation [35]. For this reason it is crucial to keep a constant number of ENMs per surface area of exposed cells in each experiment, depending on exposure conditions (such as size of plate or medium volume). Each laboratory has its own validated protocols, including cell density or medium composition. These parameters can also have significant impact on final results and can cause difficulties in comparisons with other research groups $[13,35]$. In our study, we optimized exposure volume, to keep the same amount of ENMs per surface area in all experiments. We also expressed concentrations as ENMs per cell $[\mu \mathrm{g} /$ cell and ENM $\mathrm{cm}^{2} /$ cell] to simplify comparison with studies of other researchers, according to the proposals of Stone et al. and Huk et al. [13, 36]. Nanotoxicology research requires quality assurance, with the inclusion of a range of controls to exclude false positive/negative results, not related to nano-responses. In the HPRT gene mutation assay, we observed strong mutagenic effects with two of six tested stabilizers: sodium citrate and Tween 80. Toxicity of citrate-stabilized Ag ENMs was investigated previously [23, 37-39]. However, in none of these studies was the toxicity of stabilizers taken into consideration. In our study, we found a strong mutagenic effect of sodium citrate at a concentration $0.002 \% \mathrm{w} / \mathrm{v}$ and of Tween 80 at a 


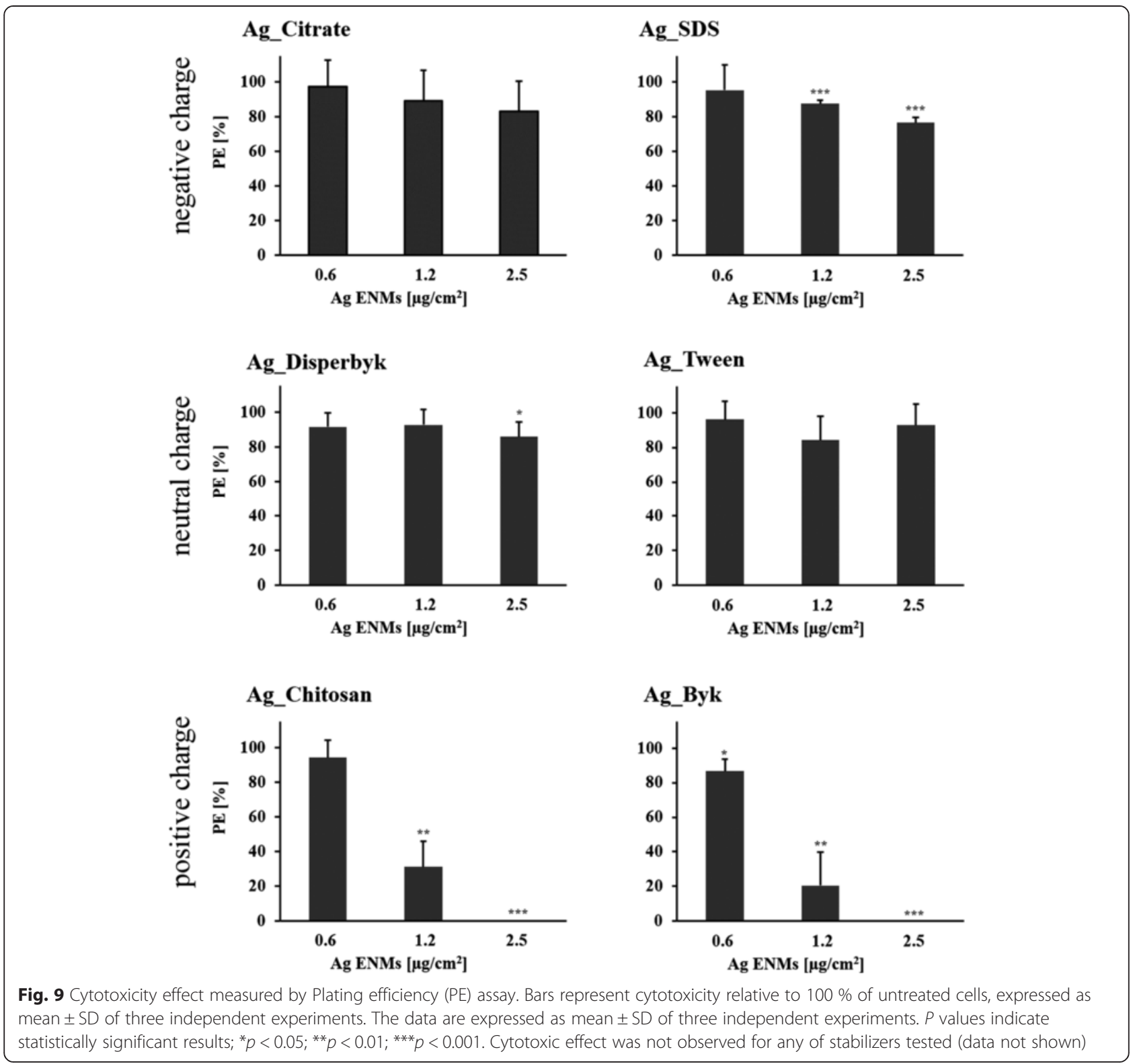

concentration of $0.008 \% \mathrm{w} / \mathrm{v}$. Similar findings were already reported by Wang et al., who have shown that photo-mutagenic effects of gold ENMs are related not only to ENMs but also to citrate ions used as a stabilizer [40]. Our results have an implication for the 'safety by design' approach, indicating that stabilizers with mutagenic potency should not be used in ENM synthesis.

Additionally, we observed unusual phenomena in samples treated by chitosan, under the light microscope. Abnormal clumps were present, in both cells treated by Ag_Chitosan and cells treated only with chitosan. Also in DLS characterization of Ag_Chitosan in biological medium, Ag ENM agglomerates were about 10 times bigger than found with other $\mathrm{Ag}$ ENMs. Precipitation of chitosan at the neutral $\mathrm{pH}$ of cell culture medium is a possible explanation of this observation.

The use of well-characterized reference ENMs is a crucial aspect of in vitro nanotoxicology studies, because the toxic potential of ENMs is strictly dependent on their physico-chemical properties. Hydrodynamic size plays a crucial role in the interaction of ENMs with living organisms. Smaller Ag ENMs were found to be more cytotoxic, genotoxic and stronger inducers of ROS production compared to bigger Ag ENMs [23-27, 41]. Size-dependent toxicity of Ag ENMs is combined with faster kinetics of dissolution and higher numbers and surface area of ENMs 
Table 3 Concentrations of Ag ions in Ag ENM samples and Ag ions released after incubation in cell culture media were evaluated by ICP-MS. Ag ions in Ag ENM stock were expressed as \% of total Ag in Ag ENM samples. Ag ions were isolated from Ag ENMs by (a) extraction and (b) by ultracentrifugation. Ag ions released during $24 \mathrm{~h}$ incubation in cell culture medium were quantified by CP-MS and expressed as percentage of the total added Ag ENMs. Results are presented as mean \pm standard deviation of 3-6 replicates

\begin{tabular}{|c|c|c|c|}
\hline & \multicolumn{2}{|c|}{$\mathrm{Ag}$ ions (\%) in stock } & \multirow[b]{2}{*}{$\begin{array}{l}\text { Released } \\
\mathrm{Ag} \text { ions } \\
\text { after } 24 \mathrm{~h} \\
\text { incubation } \\
\text { in cell } \\
\text { culture } \\
\text { medium }\end{array}$} \\
\hline & $\begin{array}{l}\text { Obtained by } \\
\text { extraction }\end{array}$ & $\begin{array}{l}\text { Obtained by } \\
\text { ultracentrifugation }\end{array}$ & \\
\hline Ag_Citrate & $12.16 \pm 5.19$ & $8.41 \pm 0.64$ & $7.02 \pm 3.27$ \\
\hline Ag_SDS & $13.81 \pm 2.49$ & $7.28 \pm 2.56$ & $6.44 \pm 1.93$ \\
\hline Ag_Disperbyk & $25.72 \pm 4.33$ & $15.86 \pm 0.49$ & $5.25 \pm 1.37$ \\
\hline Ag_Tween & $19.12 \pm 1.93$ & $7.72 \pm 1.45$ & $6.68 \pm 1.87$ \\
\hline Ag_Chitosan & $x$ & $14.37 \pm 9.6$ & $11.34 \pm 6.37$ \\
\hline Ag_Byk & $x$ & $13.59 \pm 5.63$ & $3.94 \pm 0.04$ \\
\hline
\end{tabular}

$\mathrm{x}-\mathrm{Ag}$ ion concentrations cannot be determined for the positively charged $\mathrm{Ag}$ ENMs using this approach

[23-25]. Shape is the next parameter shown to have a significant impact on Ag ENM toxicity. It was found that whereas Ag ENMs strongly affected cell viability and cytotoxicity and decreased the calcium level in epithelial lung cells, spherical Ag ENMs had no harmful effect in the same concentration range [42]. In a bacterial model, triangular Ag ENMs had a bigger effect on E. coli compared with spherical and rod shaped ENMs [43]. Chemical composition of the ENM surface is another crucial characteristic. Citrate-stabilized Ag ENMs were found to have a stronger effect on human skin keratinocytes cytotoxicity than PVP-stabilized Ag ENMs [39]. In addition, much higher expression of Rad51 protein, a biomarker of double strand breaks, was found in mouse embryonic stem cells and mouse embryonic fibroblasts treated with polysaccharide surface functionalized Ag ENMs in comparison to nonfunctionalized Ag ENMs [44]. The last significant parameter which seriously affects Ag ENM toxicity is surface charge. It is believed that positively charged ENMs are potentially more harmful than materials with negative or neutral charge. Suresh et al. have shown that the cationic Ag ENMs stabilized by poly(diallyldimethylammonium) chloride had a stronger impact on cell membrane integrity and cytotoxicity compared with anionic $\mathrm{Ag}$ ENMs [28]. Higher DNA damage was also observed in human fibroblasts and fibrosarcoma cells exposed to cationic iron oxide magnetic ENMs, whereas at the same concentrations anionic ENMs showed only a slight or no effect [45].

Since toxicity of ENMs is strictly related to their physico-chemical properties, all studied materials were synthesized in such a way that the only parameter differentiating them was their surface chemistry. In addition,

Table 4 Summary of cellular responses to Ag ENMs with different surface charge and chemical composition

\begin{tabular}{|c|c|c|c|c|c|c|c|c|}
\hline \multirow{2}{*}{$\begin{array}{l}\text { Surface charge: } \\
\text { Surface chemical composition: }\end{array}$} & & & \multicolumn{2}{|c|}{ Negative } & \multicolumn{2}{|l|}{ Neutral } & \multicolumn{2}{|l|}{ Positive } \\
\hline & & & Citrate & SDS & Disperbyk & Tween & Chitosan & Byk \\
\hline \multirow[t]{3}{*}{ Intercellular localisation } & Cytoplasm & $24 \mathrm{~h}$ & + & + & + & + & + & + \\
\hline & Nucleus & $24 \mathrm{~h}$ & - & - & - & - & + & + \\
\hline & Mitochondria & $24 \mathrm{~h}$ & - & - & - & - & + & - \\
\hline \multirow[t]{5}{*}{ Cytotoxicity } & Cells morphology & $2 \mathrm{~h}$ & - & - & - & - & $+(\mathrm{s})$ & + \\
\hline & & $24 \mathrm{~h}$ & + & + & - & - & $+(s)$ & + \\
\hline & Trypan blue exclusion & $2 \mathrm{~h}$ & - & - & - & - & + & ++ \\
\hline & & $24 \mathrm{~h}$ & - & - & - & - & ++ & ++ \\
\hline & Relative Growth Activity & $24 \mathrm{~h}$ & ++ & ++ & - & ++ & +++ & +++ \\
\hline \multirow[t]{5}{*}{ Genotoxicity and mutagenicity } & Comet assay - Strand breaks & $2 \mathrm{~h}$ & + & & & & ++ & ++ \\
\hline & & $24 \mathrm{~h}$ & ++ & + & ++ & + & $(x)$ & $(x)$ \\
\hline & Comet assay - Oxidative DNA lesions & $2 \mathrm{~h}$ & +++ & +++ & +++ & +++ & +++ & +++ \\
\hline & & $24 \mathrm{~h}$ & +++ & ++ & ++ & +++ & $(x)$ & $(x)$ \\
\hline & HPRT gene mutation & $24 \mathrm{~h}$ & $++(s)$ & + & + & $++(s)$ & + & ++ \\
\hline
\end{tabular}

The relative tendency of each $\mathrm{Ag}$ ENMs to induce cellular responses related to uptake, viability, cytotoxicity, genotoxicity and mutagenicity after 2-24 h exposure $(-)$ no harmful effects were observed in any of tested concentrations

$(+)$ indicates a significant increase in the intracellular event in one from three-five tested concentrations/localisation in selected cells compartments/change in cells morphology

$(++)$ indicates a significant increase in the intracellular event in two-three from three-five tested concentrations

$(+++)$ a significant increase in the intracellular event in one from four-five tested concentrations

(s)- Toxic effect of Ag ENMs stabilizers

(x)- Fully biological effect could not be evaluated due to strong method saturation 
to distinguish between effects of surface charge and surface chemical composition two different stabilizers per charge were selected.

For our study, ENMs with different surface charge were selected. However, after $24 \mathrm{~h}$ incubation of $\mathrm{Ag}$ ENMs in cell culture medium, we observed changes in zeta potential of cationic and anionic ENMs. This phenomenon is related to the binding of biomolecules onto the surface of ENMs, a process named protein corona formation. Due to high surface area, ENMs progressively and selectively adsorb biomolecules, such as proteins and lipids, when they come into contact with complex biological fluids [46, 47]. Formation of a protein corona is a dynamic process, because different molecules are attracted to the ENM surface at different time points. Schlinkert et al. [48] demonstrated that cationic Ag ENMs changed their surface charge, depending on how long they are incubated in cell culture medium. What is more, the chemical composition of the protein corona is also dependent on ENM surface charge, as different molecules will be attracted by cationic and anionic ENMs [49]. Cationic ENMs decrease zeta potential, in contrast to anionic ENMs. We have not observed significant changes in zeta potential of neutral ENMs, consistent with previous reports, which can be explained by low interaction between neutral ENMs and proteins [49].

The cytotoxic effect of Ag ENMs has been widely studied, and many researchers have reported that Ag ENMs could reduce cell viability, cause cell membrane damage, decrease the level of calcium, cause perturbation of mitochondria, inhibit cell proliferation, or induce apoptosis and necrosis [14-21]. In our study we found that cationic Ag ENMs are the most cytotoxic; they strongly affected cell membrane and cell morphology, inhibited proliferation and induced cells death, consistent with previous reports [28].

Genotoxicity testing in a regulatory perspective requires a battery of tests addressing these different genotoxic and mutagenic endpoints, since no single method is capable of detecting all different forms of genome damage including DNA lesions, chromosome aberration or mutation [50,51].

Our results showed that most of the tested Ag ENMs were genotoxic, and significantly increased the levels of oxidized purines and DNA strand breaks, consistent with our previous experiments and other reports $[15,23,25,52]$. The most significant effects were observed in cells treated with the two cationic Ag ENMs, Ag_Byk and Ag_Chitosan, with significant genotoxic effects already after $2 \mathrm{~h}$ exposure. However, cytotoxicity was often seen, especially after $24 \mathrm{~h}$ exposure. Early apoptosis or necrosis may lead to an elevated \% DNA in the tail giving false positive results in the CA. However, in our case, maximum cytotoxicity was
$20-30 \%$, at the highest concentration used, and so a significant influence on the CA results is unlikely.

To investigate the impact of Ag ENMs and surface composition on mutant frequency, we applied the HPRT gene mutation assay. Only a few studies of mutagenic effects of Ag ENMs are available so far [53-56]; most employed the Ames test, an assay which has strong limitations when applied in nanotoxicology [50]. A study using a mammalian model also reported no mutagenic effects of Ag ENMs; however, it is difficult to refer to this study because of big differences in the materials used, and lack of detailed characterization [56].

In our study, to investigate the impact of Ag ENMs on gene mutation, instead of the Ames test, the $\mathrm{X}$ chromosome-linked hemizygous HPRT gene mutation assay was applied. The main advantages of this assay are that it is based on a mammalian cell line, selection of mutants with 6-thioguanine is simple, there is no interference with nanomaterials, it has the capacity to characterise the diverse range of possible mutations, and only one allele needs to be inactivated for the mutation to be expressed [57].

In our study we found that all six tested Ag ENMs induced mutants in V79-4 cells. We have to exclude false positive results of Ag_Tween and Ag_Citrate, due to strong mutagenic effects of Ag ENM stabilizers. Among all tested Ag ENMs Ag_Byk showed a clear positive effect and could be considered as mutagenic. Ag_SDS, Ag_Disperbyk and Ag_Chitosan were found to be weakly positive and further investigation would be needed to confirm their mutagenicity. In our previous experiments on nanomaterial mutagenicity, Ag ENMs with sizes 50, 80 and $200 \mathrm{~nm}$ were tested [25]. In that study, we observed a clear reverse concentration-response, for all tested materials. Discrepancies between these two studies can be explained by differences in investigated materials. In a study of size-related toxicity, PVP was applied to prevent protein binding to the surface of Ag ENMs, Ag ENM agglomeration and dissolution [49, 58]. PVPstabilized Ag ENMs keep their primary shape and size during all exposure times in contrast to Ag ENMs tested in the present experiment. Different ranges of tested concentrations can also explain other biological responses. In a study of size-related toxicity, a wider concentration range of Ag ENMs was used (0.21-15.9 $\mu \mathrm{g} /$ $\mathrm{cm}^{2}$ ) [25]. At a high concentration, there was a dramatic increase and accumulation of various kinds of DNA damage, and mutants lost their survival ability, which can explain the reverse-concentration trend. We also observed that the mutagenic potential of Ag ENMs is dependent to some degree on cytotoxicity. Ag ENMs with negative and neutral charge (also PVP-stabilized Ag ENMs) decreased cell viability only slightly or not at all, but greatly induced the frequency of $H P R T$ gene mutants 
in contrast to Ag_Byk and Ag_Chitosan, which are highly cytotoxic (even after washing) and also greatly induced gene mutations in V79-4 cells. In summary Ag ENMs can cause gene mutations, at both non-cytotoxic and cytotoxic concentrations, depending on their physico-chemical properties. Low concentrations of Ag ENMs increased the level of HPRT gene mutants, up to the point at which the level of DNA damage was so high that mutants lost their survival ability.

High cytotoxic and genotoxic effects of Ag_Chitosan and Ag_Byk can be explained by different uptake mechanisms and subcellular localization of ENMs. The cell membrane, due to its negative charge, is more attractive for cationic ENMs rather than anionic. Kralj et al. [59] in their study on charge dependent uptake, showed that positively charged, magnetic ENMs were internalized by a human breast epithelial cell to a much greater extent than were negatively charged ENMs. However, ENM charge did not have any impact on subcellular localization, because both cationic and anionic magnetic ENMs were localized in lysosomes. Moreover Asati et al. [60] found that cerium oxide ENMs with neutral charge were found mostly in cytoplasm, in contrast to cationic and anionic ENMs, which were located in both cytoplasm and lysosomes.

In our study, we found that all six tested Ag ENMs were taken up by TK6 cells, and Ag ENMs were present mostly in the cytoplasm. However, we also found cationic ENMs in the nucleus and mitochondria. The presence of ENMs in these organelles was already reported $[15,16,25,61]$ and suggests that Ag ENMs can have direct contact with DNA. Ag ENMs can enter the nucleus by penetration or during mitosis and interact or bind with DNA molecules or affect DNA replication and transcription [62], which could explain the much higher level of different DNA lesions in cells treated by cationic Ag ENMs compared with anionic or neutral.

During exposure in cell culture medium, Ag ENMs can slowly dissolve to $\mathrm{Ag}$ ions. $\mathrm{Ag}$ ions can reduce cell viability and stimulate ROS production; however, it is still not clear how significant an impact the Ag ions have on total Ag ENM toxicity [17,63]. The experiments with an ion fraction (obtained from Ag ENMs by ultracentrifugation after incubation of $\mathrm{Ag}$ ENMs in cell culture medium), have shown no effect on cell viability or genotoxicity [23, 27, 42, 58]. This is mostly because the concentrations of released ions were relatively low, at 2-20 \% of the applied concentration of Ag ENMs (depended on Ag ENMs shape, size and surface coating), and were found to be insufficient to cause toxic effects. A significant fact is also that $\mathrm{Ag}$ in nano-form is more efficiently taken up by the cells than is $\mathrm{Ag}$ in ion form $[64,65]$.

In our study we found no significant impact of surface composition/charge on the dissolution rate of Ag ENMs in cell culture medium, consistent with a previous report [23]. Our results suggested that subcellular Ag ENM dissolution, rather than extracellular, plays significant roles in Ag ENM toxicity.

In our experiments, both cationic Ag ENMs caused membrane damage, inhibited cell proliferation and induced strand breaks and DNA oxidation. However, Ag_Byk were also found to be mutagenic and induced cell cytotoxicity at lower concentration than Ag_Chitosan. We found that Ag_Byk created much smaller agglomerates in the rich protein medium $(\sim 40 \mathrm{~nm})$ compared to Ag_Chitosan $(\sim 700-1200 \mathrm{~nm})$, which suggests that not only dissolution of Ag ions, but also agglomeration state can have a crucial impact on Ag ENMs toxicity, as already suggested by Lankoff et al. [23] and Gliga et al. [61]. Agglomerated Ag ENMs were found be less toxic. Several authors suggest that it may be mostly due to reduction of specific surface area, slowing the ENM dissolution, and inhibition of ENM uptake [23, 30, 61].

\section{Conclusion}

We investigated the impact of Ag ENM surface charge and composition on cell cytotoxicity, genotoxicity and mutagenicity. Agglomeration, dissolution and uptake were additionally investigated as crucial aspects of $\mathrm{Ag}$ ENM toxicity. We found that positive Ag ENMs had greater impact on cell proliferation, cell death, membrane disintegration and DNA damage than Ag ENMs with neutral or negative charge. Severe genotoxic effects of cationic Ag ENMs can be combined with the presence of Ag ENMs in the nucleus and mitochondria, which suggests that Ag ENMs can induce toxicity by both direct contact with DNA and indirect (via oxidative stress) mechanisms. Our experiments with the HPRT gene mutation assay demonstrated that not only surface charge but also surface chemical composition play a significant role in Ag ENM toxicity.

\section{Abbreviations \\ CA: Comet assay; DLS: Dynamic light scattering; ENMs: Engineered nanomaterials; FPG: Formamidopyrymidine DNA glycosylase; OECD: Organization for Economic Co-operation and Development; PE: Plating efficiency; PVP: Polyvinylpyrrolidone; RGA: Relative growth activity; SDS: Sodium dodecyl sulphate; TBE: Trypan blue exclusion assay; TK6: Human B-lymphoblastoid cell line; TEM: Transmission electron microscopy; V79-4: Chinese hamster lung fibroblast cells; XPS: X-ray photoelectron spectroscopy; XRD: X-ray diffraction.}

\section{Competing interest}

The authors declare that they have no competing interest.

\section{Authors' contributions}

$\mathrm{AH}$ was involved in the design of the study, prepared samples for ion release and characterization in biological medium, performed uptake studies, carried out all biological based experimentation, and drafted the manuscript. EIN synthesized nanomaterials and performed primary characterization. NEY participated on biological experiments with the comet assay. HU and MV performed experiments with ICP-MS. BZ measured DLS and zeta potential, $A D$ is overall project leader and contributed intellectually and with revising 
the manuscript. MD is PhD supervisor of $A H$, was involved in the planning and technical aspects of the study, and helped with interpretation of the data and revising the draft manuscript. All authors read and approved the final manuscript.

\section{Acknowledgement}

This research was supported by the EU 7th framework program, Marie Curie Actions, Network for Initial Training NanoTOES (PITN-GA-2010-264506), EC FP7 QualityNano [INFRA-2010-1.131], contract No: 214547-2, and EC FP7 NANoREG, [NMP.2012.1.3-3] contract No: 310584. We thank Mr. Leszek Huk for making the plate for incubation slides and Mr. Michal Zagrodzki for help with graphic design and Prof. Andrew Collins for providing FPG enzyme and for English corrections. Ro 19-8022 was a generous gift from Hoffmann La Roche.

\section{Author details \\ 'Health Effects Laboratory, MILK, NILU, Kjeller, Norway. ${ }^{2}$ Department of Molecular Biology, University of Salzburg, Salzburg, Austria. ${ }^{3}$ Bayer Technology Services GmbH, Leverkusen, Germany. ${ }^{4}$ Inorganic Group, MILK, NILU, Kjeller, Norway. ${ }^{5}$ Institute of Macromolecular Chemistry, Academy of Sciences of the Czech Republic, Prague, Czech Republic.}

\section{Received: 18 December 2014 Accepted: 6 July 2015} Published online: 24 July 2015

\section{References}

1. U.S. Environmental Protection Agency. State of the Science Literature Review: Everything Nanosilver and More. 2010.

2. Likus W, Bajor G, Siemianowicz K. Nanosilver — does it have only one face? Acta Biochemica Polonica. 2013:4:495-501

3. Lem KW, Chudhury A, Lakhani AA, Kuyate P, Haw JR, Lee DS, et al. Use of nanosilver in consumer products. Recent Pat Nanotechnol. 2012;6:60-72.

4. Schluesener JK, Schluesener HJ. Nanosilver: application and novel aspects of toxicology. Arch Toxicol. 2013;87:569-76.

5. Sarsar V, Selwal KK, Selwa MK. Nanosilver: potent antimicrobial agent and its biosynthesis. Afr J Biotechnol. 2014;13:5-46.

6. Dastjerdi R, Montazer M. A review on the application of inorganic nano-structured materials in the modification of textiles: focus on anti-microbial properties. Colloids Surf B Biointerfaces. 2010;79:5-18.

7. Brar SK, Verma M, Tyagi RD, Surampalli RY. Engineered nanoparticles in wastewater and wastewater sludge - evidence and impacts. Waste Manag. 2010;30:504-20.

8. Li Q, Mahendra S, Lyon DY, Brunet L, Liga MV, Li D, et al. Antimicrobial nanomaterials for water disinfection and microbial control. Potential applications and implications. Water Res. 2008;42:4591-602.

9. Sotiriou GA, Pratsinis SE. Engineering nanosilver as an antibacterial, biosensor and bioimaging material. Curr Opin Chem Eng. 2011;1:3-10.

10. Hamouda IM. Current perspectives of nanoparticles in medical and dental biomaterials. J Biomed Res. 2010;26:143-51.

11. Nowack B, Krug HF, Height M. 120 years of nanosilver history: implication for policy makers. Envir Scien Tech. 2011;45:1177-83.

12. Chalupka K, Malam Y, Seifalian AM. Nanosilver as a new generation of nanoproduct in biomedical applications. Trends Biotechnol. 2010;28:580-8.

13. Stone V, Jahnston H, Schins RPF. Development of in vitro systems for nanotoxicology: methodological considerations. Crit Rev Toxicol. 2009;39:613-26.

14. Babu K, Deepa M, Shankar SG, Rai S. Effect of nano-silver on cell division and mitotic chromosomes: a prefatory siren. Internet J Nanotech. 2008;2:2-5.

15. AshaRani PV, Low Kah Mun G, Hande MP, Valiyaveettil S. Cytotoxicity and genotoxicity of silver nanoparticles in human cells. ACS Nano. 2008:3:279-90.

16. Zanette C, Pelin M, Crosera M, Adami G, Bovenzi M, Larese FF, et al. Silver nanoparticles exert a long-lasting antiproliferative effect on human keratinocyte HaCaT cell line. Toxicol In Vitro. 2011;25:1053-60.

17. Foldbjerg R, Olesen P, Hougaard M, Dang DA, Hoffmann HJ, Autrup H. PVP-coated silver nanoparticles and silver ions induce reactive oxygen species, apoptosis and necrosis in THP-1 monocytes. Toxicol Lett. 2009;190:156-62

18. Piao MJ, Kang KA, Lee IK, Kim HS, Kim S, Choi JY, et al. Silver nanoparticles induce oxidative cell damage in human liver cells through inhibition of reduced glutathione and induction of mitochondria-involved apoptosis. Tox Lett. 2011;201:92-100.

19. Asare N, Instanes C, Sandberg WJ, Refsnes M, Schwarze P, Kruszewski M, et al. Cytotoxic and genotoxic effects of silver nanoparticles in testicular cells. Toxicology. 2011;291:65-72.

20. Hackenberg S, Scherzed A, Kessler M, Hummel S, Technau A, Froelich K, et al. Silver nanoparticles: evaluation of DNA damage, toxicity and functional impairment in human mesenchymal stem cells. Toxicol Lett. 2011;201:2733.

21. Foldbjerg R, Dang DA, Autrup H. Cytotoxicity and genotoxicity of silver nanoparticles in the human lung cancer cell line, A549. Arch Toxicol. 2011;85:743-50.

22. Jones CF, Grainger DW. In vitro assessments of nanomaterial toxicity. Adv Drug Deliv Rev. 2009;61:438-56.

23. Gliga AR, Skoglund S, Wallinder IO, Fadeel B, Karlsson HL. Size-dependent cytotoxicity of silver nanoparticles in human lung cells: the role of cellular uptake, agglomeration and Ag release. Part Fibre Toxicol. 2014;11:11.

24. Liu W, Wu Y, Wang C, Li HC, Wang T, Liao CY, et al. Impact of silver nanoparticles on human cells: effect of particle size. Nanotoxicology. 2010;4:319-30

25. Huk A, Izak-Nau E, Reidy B, Boyles M, Duschl A, Lynch I, et al. Is toxic potential of nanosilver dependent on its size? Part Fibre Toxicol. 2014;11:65. PMID:25466209

26. Park MVDZ, Neigh AM, Vermeulen JP, Fonteyne LJJ, Verharen HW, Briedé JJ, et al. The effect of particle size on the cytotoxicity, inflammation, developmental toxicity and genotoxicity of silver nanoparticles. Biomaterials. 2011;32:9810-7

27. Ivask A, Kurvet I, Kasemets K, Blinova I, Aruoja V, Suppi S, et al. Size-dependent toxicity of silver nanoparticles to bacteria, yeast, algae, crustaceans and Mammalian cells in vitro. PLoS One. 2014;9(7):e102108.

28. Suresh AK, Pelletier DA, Wang W, Morrell-Falvey JF, Gu B, Doktycz MJ. Cytotoxicity Induced by Engineered Silver Nanocrystallites is dependent on surface coating and cell types. Langmuir. 2012;28:2727-35.

29. El Badawy AM, Silva RG, Morris B, Scheckel KG, Suidan MT, Tolaymat TM. Surface charge-dependent toxicity of silver nanoparticles. Environ Sci Technol. 2011:45:283-7.

30. Magdolenova Z, Drlickova M, Henjum K, Rundén-Pran E, Tulinska J, Bilanicova D, et al. Coating-dependent induction of cytotoxicity and genotoxicity of iron oxide nanoparticles. Nanotoxicology. 2015;9(S1):44-56.

31. Creighton JA, Blatchford CG, Albrecht MG. Plasma resonance enhancement of Raman scattering by pyridine adsorbed on silver or gold sol particles of size comparable to the excitation wavelength. J Chem Soc Farad Trans II. 1979;75:790-8.

32. Catalán J, Suhonen S, Huk A, Dusinska M. CHAPTER 14. Analysis of nanoparticle-induced DNA damage by the comet assay. In: Maria Sierra L, Isabel G, editors. Genotoxicity and Repair. A Practical Approach, Methods in Pharmacology and Toxicology. Heidelberg Dordrecht London: Springer Protocols, Humana Press, Springer New York; 2014. p. XII, 483. 70 illus., 42 illus. in color.ISSN 1557-2153, pp 241-268.

33. Dusinska M, Collins AR. Detection of oxidised purines and UV-induced photoproducts in DNA, by inclusion of lesion-specific enzymes in the comet assay (single cell gell electrophoresis). ATLA. 1996;24:405-11.

34. Foldbjerg $\mathrm{R}$, Autrup $\mathrm{H}$. Mechanisms of silver nanoparticles toxicity. Arch Bas App Med. 2013;1:5-15.

35. Reidy B, Haase A, Luch A, Dawson KA, Lynch I. Mechanisms of silver nanoparticle release transformation and toxicity: a critical review of current knowledge and recommendations for future studies and applications. Materials. 2013;6:2295-350.

36. Huk A, Collins AR, Yamani N, Porredon C, Azqueta A, de Lapuente J, et al. Critical factors to be considered when testing nanomaterials for genotoxicity with the comet assay. Mutagenesis. 2015;30(1):85-8.

37. Sahu SC, Zheng J, Grahamb L, Chenc L, Ihried J, Youricka JJ, et al. Comparative cytotoxicity of nanosilver in human liver HepG2 and colon Caco2 cells in culture. J Appl Toxicol. 2014;34:1155-66.

38. Powers CM, Badireddy AR, Ryde IT, Seidler FJ, Slotkins TA. Silver nanoparticles compromise neurodevelopment in PC12 cells: critical contributions of silver ion, particle size, coating and composition. Environ Health Perspect. 2011;119:37-44.

39. Lu W, Senapati D, Wang S, Tovmachenko O, Singh AK, Yu H, et al. Effect of surface coating on the toxicity of silver nanomaterials on human skin keratinocytes. Chem Phys Lett. 2010;487:92-6. 
40. Wang S, Lawson R, Ray PC, Yu H. Toxic effects of gold nanoparticles on Salmonella typhimurium bacteria. Toxicol Ind Health. 2011;27:547-54.

41. Carlson C, Hussain SM, Schrand AM, Braydich-Stolle LK, Hess KL, Jones RL, et al. Unique cellular interaction of silver nanoparticles: size dependent generation of reactive oxygen species. J Phys Chem B. 2008;112:13608-19.

42. Stoehr LC, Gonzalez E, Stampfl A, Casals E, Duschl A, Puntes V, et al. Shape matters: effects of silver nanospheres and wires on human alveolar epithelial cells. Part Fibre Toxicol. 2011;8:36-51.

43. Pal S, Tak YK, Song JM. Does the antimicrobial activity of silver nanoparticles depend on the shape of the nanoparticle? A study of the gram-negative bacterium Escherichia coli. Appl Environ Microbiol. 2007;73:1712-20.

44. Ahamed M, Karns M, Goodson M, Rowe J, Hussain SM, Schlager JJ, et al. DNA damage response to different surface chemistry of silver nanoparticles in mammalian cells. Toxicol Appl Pharma. 2008;233:404-10.

45. Yang WJ, Lee JH, Hong SC, Lee J, Jaebeom Lee J, Han DW. Difference between toxicities of iron oxide magnetic nanoparticles with various surface-functional groups against human normal fibroblasts and fibrosarcoma cells. Materials. 2013;5:4689-706.

46. Monopoli MP, Åberg C, Salvati A, Dawson KA. Biomolecular coronas provide the biological identity of nanosized materials. Nat Nanotechnol. 2012:7:779-86

47. Casals E, Pfaller T, Duschl A, Oostingh GJ, Puntes VS. Hardening of the nanoparticle-protein corona in metal ( $\mathrm{Au}, \mathrm{Ag}$ ) and oxide (Fe $3 \mathrm{O}$ 4, $\mathrm{CoO}$ and CeO 2) nanoparticles. Small. 2011;7:3479-86.

48. Schlinkert P, Casals E, Boyles M, Tischler U, Hornig E, Tran N, et al. The oxidative potential of differently charged silver and gold nanoparticles on three human lung epithelial cell types. J Nanobiotechnology. 2015;13:1.

49. Izak-Nau E, Voetz M, Eiden S, Duschl A, Puntes VF. Altered characteristics of silica nanoparticles in bovine and human serum: the importance of nanomaterial characterization prior to its toxicological evaluation. Part Fimb Toxicol. 2013;10:56-68.

50. Doak SH, Manshian B, Jenkins GJ, Singh N. In vitro genotoxicity testing strategy for nanomaterials and the adaptation of current OECD guidelines. Mutat Res. 2012;14:104-11.

51. Dusinska M, Magdolenova Z, Fjellsbø LM. Toxicological aspects for nanomaterial in humans. Methods Mol Biol. 2013:948:1-12.

52. Hudecová A, Kusznierewicz B, Rundén-Pran E, Magdolenová Z, Hasplová K, Rinna A, et al. Silver nanoparticles induce premutagenic DNA oxidation that can be prevented by phytochemicals from Gentiana asclepiadea. Mutagenesis. 2012;6:759-69.

53. Tedsree K, Tiyawat W, Ketaram K, Phetlert C. Synthesis and mutagenicity of silver nanoparticles with different sizes and shapes. Pure and applied chemistry international conference 2013 (PACCON 2013).

54. Kim HR, Park YJ, da Shin Y, Oh SM, Chung KH. Appropriate in vitro methods for genotoxicity testing of silver nanoparticles. Environ Health Toxicol. 2013;28:e2013003.

55. Li Y, Chen DH, Yan J, Chen Y, Mittelstaedt RA, Zhang Y, et al. Genotoxicity of silver nanoparticles evaluated using the Ames Test and in vitro micronucleus assay. Mutat Res. 2012;745:4-10.

56. Kim JY, Yang SI, Ryu JC. Cytotoxicity and genotoxicity of nanosilver in mammalian cell lines. Mol Cell Toxicol. 2010;6:119-25.

57. Johnson GE. Mammalian cell HPRT gene mutation assay: test methods. Methods Mol Biol. 2012;817:55-67.

58. Wang $\mathrm{X}$, Ji Z, Chang CH, Zhang H, Wang M, Liao YP, et al. Use of coated silver nanoparticles to understand the relationship of particle dissolution and bioavailability to cell and lung toxicological potential. Small. 2014;10:385-98.

59. Kralj S, Rojnik M, Romih R, Jagodic M, Kos J, Makovec D. Effect of surface charge on the cellular uptake of fluorescent magnetic nanoparticles. J Nanopart Res. 2012;12:1151.

60. Asati A, Santra S, Kaittanis C, Perez JM. Surface-charge-dependent cell localization and cytotoxicity of cerium oxide nanoparticles. ACS Nano. 2010;4:5321-31.

61. Lankoff A, Sandberg WJ, Wegierek-Ciuk A, Lisowska H, Refsnes M, Sartowska $B$, et al. The effect of agglomeration state of silver and titanium dioxide nanoparticles on cellular response of HepG2, A549 and THP-1 cells. Toxicol Lett. 2012;208:197-213.

62. Magdolenova Z, Collins AR, Kumar A, Dhawan A, Stone V, Dusinska M. Mechanisms of genotoxicity. Review of recent in vitro and in vivo studies with engineered nanoparticles. Nanotoxicology. 2014:8:233-78.
63. Eom HJ, Choi J. p38 MAPK activation, DNA damage, cell cycle arrest and apoptosis as mechanisms of toxicity of silver nanoparticles in Jurkat T cells. Environ Sci Technol. 2010;44:8337-0342.

64. Prasad RY, McGee JK, Killius MG, Suarez DA, Blackman CF, DeMarini DM, et al. Investigating oxidative stress and inflammatory responses elicited by silver nanoparticles using high-throughput reporter genes in HepG2 cells: effect of size, surface coating, and intracellular uptake. Toxicol In Vitro. 2013;27:2013-21.

65. Cronholm P, Karlsson HL, Hedberg J, Lowe TA, Winnberg L, Elihn K, et al. Intracellular uptake and toxicity of $\mathrm{Ag}$ and $\mathrm{CuO}$ nanoparticles: a comparison between nanoparticles and their corresponding metal ions. Small. 2013;9:970-82.

\section{Submit your next manuscript to BioMed Central and take full advantage of:}

- Convenient online submission

- Thorough peer review

- No space constraints or color figure charges

- Immediate publication on acceptance

- Inclusion in PubMed, CAS, Scopus and Google Scholar

- Research which is freely available for redistribution 